\title{
Walter Benjamin'de Tipler, İmge ve Deneyim
}

\author{
Engin Ümer*
}

\section{Özet}

Modernite, deneyimin tehlikeye girmesidir. Bu tehlike deneyimin otantik benliği besleyen bilme, eyleme ve tat alma yetilerinin başkalaşmasıdır. Bu başkalık toplumsal biraradahı̆ın kalmaması, doğa ile birey arasındaki mesafenin artması, deneyimin araçsallaşması gibi bir dizi semptomla anlaşılabilir. Walter Benjamin bu perspektifi güçlü bir şekilde kurmuş ve modernliğin sonuçları ve onların nasıl aşılması gerektiği konusunda düşünmüş isimlerdendir. Bu çalışma günümüzde Benjamin'in önerilerini düşünmeyi amaçlamıştır. Benjamin'in yaşamının izinde düşüncesinin önemli figürlerini (çocuk, koleksiyoncu, hikâye anlatıcısı, flaneur, üretici olarak yazar) ele alan çalışma devam eden kısımlarda fotoğraf ve sinema deneyimine yer vermektedir. Temel sorun insanın kendi varoluşunun tehlikeye girdiği bir rüyayı yaşamasıdır. Buna karşılık imgeler yabancılaştırıcı teknikler kullanılarak bu rüyayı dönüştürme gücünü elinde tutmaktadır. Benjamin bu düşünceyi savunmuş ve son dönem eserlerinde sanat yapıtının teknolojiyle olan dönüşümünü konu edilmişstir. İmgenin deneyimde açtığı genişleme ve imkânlar üzerine Benjamin'in olumlu bakış açısı günümüzde kimi sanat stratejilerinde güncelliğini korumaktadır. Ancak Benjamin'in arzuladığı dönüştürücü güçlerden de yoksundurlar. Bunun nedeninin 'çocukluğun kaybedilmesi', çocukluğun deneyimden elini ayağını çekmesi olduğu bu çalışmada iddia edilmektedir. İdeolojilerin sonu (iddiasından) sonra kültürün çocukluğu düzenlemeye devam etmesi, deneyimin enformasyona dönüşmesi Benjaminci devrim düşüncesinden uzakta olduğumuzu göstermektedir.

Anahtar Kelimeler: Walter Benjamin, Deneyim, Modernite, İmge, Sanat, Kültür

\footnotetext{
${ }^{*}$ Ordu Üniversitesi, Güzel Sanatlar Fakültesi, Resim Bölümü
} İletişim: umerengin@gmail.com

Geliş Tarihi - Received: 29.09.2017

Kabul Tarihi - Accepted: 06.12.2017 


\title{
Types, Image and Experience in Walter Benjamin's Works
}

\author{
Engin Ümer*
}

\begin{abstract}
Modernity means being imperiled of the experience. This imperilment is the metamorphosis of the competences of knowing, doing and tasting which feeds the authentic ego. This metamorphosis may be understood through a series of symptoms, such as not remaining of social unity, growing of the distance between nature and the individual, the instrumentalisation of the experience and so on. Walter Benjamin is one of the people who set up this perspective in a strong way and thought about the results of the modernity and how they should be overcome. By mentioning this thought, his study tries to think about Benjamin's suggestions in this day and age. Being on the track of Benjamin's life the study examines the relevant figures (i.e., child, collector, storyteller, flaneur, the author as a producer) of his ideas and refers to photography and cinema experience in following sections. The main problem is that the human is living a dream that his own existence is imperiled. On the other hand, images retain the power to transform this dream by using alienating techniques. Benjamin advocated this idea, and in his recent works, he talked about the transformation of artwork with technology. Benjamin's positive view on the enlargement and possibilities that the image has opened up to the experience continues to be relevant in some of the artistic strategies today. However, to my knowledge, the artistic strategies are lack of the transformative power that Benjamin desires. To contribute to the literature, in the present study, the underlying reason for this is in claimed to be the 'loss of childhood,' the with drawal of childhood from experience. After the end of ideologies, the cultures continue to regulate childhood, turning the experience in to information shows that we are far from the Benjamian revolutionary thought.
\end{abstract}

Keywords: Walter Benjamin, Experience, Modernite, Image, Art, Culture.

\footnotetext{
* Ordu University, Faculty of Fine Arts, Painting Department

E-mail: umerengin@gmail.com
}

Received - Geliş Tarihi: 29.09.2017

Accepted - Kabul Tarihi: 06.12.2017 


\section{Giriş}

Bazı düşünürler yöntemleriyle anılırlar. Mesela Kant, ünlü dakikliğiyle ve çalışkanlığıyla bilinmektedir¹. Yöntemi kadar soğuk ve disiplinli bir hayat. Bazı düşünürler de yaşamlarıyla, varoluşlarının eserlerine sinmesi ya da ikisinin birbirine karışmasıyla anılırlar. Mesela Nietzsche. Coşkulu üslubunun altında hastalıklı bir bedenin kaynaması görülür². Batı kültürüne karşı gösterdiği keskin eleştiriyle eserleri anlamını bununla kazanmıştır. Bazıları ise ölümleriyle anılırlar. Platon'un, metinlerindeki canlılığını ölümüne borçlu olduğu Sokrates gibi. Ölümü bir başlangiç için geçiş sahnesidir. Kimi düşünürler ise bir ruh hali olarak anılırlar. Onlar hakkında çok şey bilinmese de eserleri incelikli okumalara tabi tutulmasa da garip bir şekilde tanıdık bir ruhsallığa ya da duygu durumuna karşılıktır. Bu gibi düşünürler fikirlerinden önce varoluşlarıyla akla girerler. Nietzsche gibilerinin karizması, Spinoza'nın mütevaziliği okuyucularının felsefelerinden çok ilgilerini çeken detaylar olması buna örnektir. Kimi düşünürlerin takipçileri çok olmasa bile ananları çoktur. Anılma nedenleri ise aykırılıklarıdır. Tarih kendi seyrinde giderken, önüne çıkanları tarihin dışına atarken onları atamaz. Onlar parıltılarıyla ilham verici olmayı her zaman sürdürürler.

Walter Benjamin böyle düşünürlerdendir. Büyük teorileri olmayan, büyük anlatılar üretmeyen isimlerdendir. Benjamin, hayaletleri çağıran, onları davet eden ve modernliğin düzenli evinin huzurunu bozan düşünürler sınıfındandır. İsmi modernliğin tarihine giden yolda çok şey söyler. Ancak hiçbiri geleceğe atılmış vahiysel sözler ('Güç İstenci' gibi) ya da köklü bir hesaplaşma ('Aydınlanmanın Diyalektiği' gibi) olarak okunmaz. O bir koleksiyoncu, arşivci ve arkeologdur. Elindeki parçaların değerini bilmek gibi bir meziyete sahiptir. Yazı işçiliği arşivde bulduklarının içerdiği tınıları hissetmek ve onları konuşturmak ile alakalıdır. Benjamin bugünkü yaşantımızın bitimsiz paradokslarını ilk görenlerden, gündelik yaşantımız hakkında ilk sözleri söyleyen, onun hakkında düşünmüş isimlerdendir. Elbette düşünürün imgesini dramatik veya trajik bir hikaye veya olay beslemiştir. Sondan başlarsak ve Benjamin hakkındaki neredeyse her yazıda değinilen trajik ölümünün O'nun zarafetini güçlendirdiğini söylemek gerekir. Zarafet Benjamin'in ölüm şekli değil, şanssız bir seçimdeki ölümü istemesidir. Daha yapacak çok işi varken.

Benjamin, ikinci dünya savaşının gölgesinde yaşam mücadelesi vermiştir. Geçmişe karşı olan ilgisi yaşadığı bu lanetli zamanlardan kaçıştır. Ancak bu kaçış, kötü bir nostaljici tutum değildir. Benjamin, kaybedilmiş olanlar hakkında ağıt yakan bir tonla konuşmamış, şimdiye neden olan sürecin peşinde ve onlardaki potansiyeli görmeyi amaçlamıştır. Faşizmin yükseldiği bir zamanda geçmişin ruhları karabasan gibi Almanya'nın üzerine ve sonra Avrupa'ya çökerken Benjamin geçmişin hayaletlerinin peşinde olmuştur. Bu hayaletler ayak

\footnotetext{
${ }^{1}$ Elbette bunun abartılı bir mit olduğu, Kant'ın da sıradan insanlara özgü tavırlara sahip olduğu söylenebilir. Bu konuda bir Kant biyografisi için E. Efe Çakmak "Kant: Filozof Kral" (Çakmak, 2005: 831).

2 Nietzsche, Ecce Homo'da hastalıklarının nasıl eserler verdirttiğini anlatır (Nietzsche, 2001: 15). Klossowski "Nietzsche ve Kısırdöngü" kitabında şöyle yazar: "Nietzsche akıl sağllğı için oluşturulan bir beden "sağlığı" için konuşmadı. Bilincin bedensel durumların bireysel bilinci olmak amaciyla saklayabildiği özgün veriler olarak bedensel durumlar için konuştu" (Klossowski, 1999: 54).
} 
takımından oluşmakta, aralarında inceltilmiş zevkleri olanlar, yazarlar, çizerler ve sanatçılar bulunmaktadır.

Bitmeyen yapıtlar, üzerine çok konuşulur ve yazı enflasyonuna neden olmalarıyla ilham vericiliklerini her zaman korurlar. Benjamin'in "Pasajlar" projesi de bunlardandır. Modern kültürün palazlanmasını, kapitalizmin gelip geçici bir iletişim düzeni kurmasını ve kitlesel hareketlerin varlık gösterirken bilinç probleminin yaşanıldığı zamanda her modern düşünürün sorunları Benjamin'de de kendisini göstermiştir: Nasıl yaşamak gerekmektedir? Devrim bunun için nasıl gerçekleştirilmelidir? Bu soruların nedeni ve onlara verilen cevaplar bir sıkıntıyla sürekli göze getirmektedir. Bu sıkıntı deneyim krizidir.

Bu çalışma Benjamin'in deneyim düşüncesi üzerine kurulmuştur. Modern kültürde deneyim sorusunu Benjamin üzerinden düşünmek ve O'nun önerilerini ele almak amacındadır. Bunu yaparken Benjamin'in yazı trafiği içinde dolaşacak, O'ndaki belli başlı temalar ve karakterler anlatılacaktır. Son kısımda ise Benjamin'in son dönem yazılarında demokratikleştirici bir sanat düşüncesi ve görme tarzı önerisi ve bunların sunduğu perspektifler ele alınacak, O'nun sanat düşüncesi deneyim olgusu üzerinden anlatılacaktır.

Çalışma kapsamında taranan literatürde, tipler üzerinden yapılan bir Benjamin okumasına rastlanmamıştır. Daha çok O'nun "Pasajlar" eserindeki tipler listesine sıkça yer verildiği görülmüştür. Bunlara karşılık Susan Buck-Morss'un ansiklopedik Benjamin okuması ya da "Pasajlar" inşasında Benjamin'deki tipler Pasajlar'da nasıl geçiyorsa tanımlanmış, özel bir okumaya girişilmemiştir (Buck-Morss, 2015). Bu yazıda tip düşüncesi ise Deleuze'ün kavramsal kişilikler düşüncesiyle Simmel'in tipler sosyolojisi arasında bir perspektifle düşünülmüştür. İlk perspektif içerisinden Benjamin'in bu çalışma için düşünülen karakterlerinin O'nun deneyim düşüncesini anlamak adına ele alındığ1 söylenebilir. Söz konusu tipler bir düşünmenin biçimlenmiş halleri olarak görülmüştür. Saf deneyim imkanı olarak çocuk, deneyimin aktarım imkanı olarak hikaye anlatıcısı, meta deneyimleri üzerine flaneur ve koleksiyoncu. İkinci açıdan ise bu tipler gerçektirler. Çocuk, şiirsel bir benzetme anlamında değil, Benjamin'in kendi çocukluğu ve çocuk üzerine düşünceleriyle tanım kazanır. Yine diğer tipler kapitalist düzenin üretimleridir ve tarihseldirler.

Son olarak bu tipler imge ile olan ilişkileri üzerinden anlamlıdırlar. Deneyimler -ki her deneyimde olduğu gibi- imgeler ile anlam kazanırlar. Çocuk, bellek imgeleri, koleksiyoncu fetiş imgeleri, flaneur kentin baştan çıkartıcı imgeleri, kitle ise fantezi imgeleri gibi. Hepsi de diyalektik imgenin içinde büyüleyici bir başkalık imkânı önermektedirler. Benjamin bunlara ek olarak imgenin kendi başına gücünü de düşünmüştür. Fotoğraf üzerine düşüncelerinde fotoğrafik imgenin sarsıcı deneyimleri bu çalışmada ele alınmıştır. Sinema deneyiminde kolektif seyir, imgenin modern kültürde otantik toplum düşüne imkân sağlaması adına bir öneri olarak okunabilir.

\section{Deneyim Alanları ve İmkânlar}

Benjamin'in ele aldığı konular çeşitlidir. Benjamin'i Paris Pasajları ile ilgilenmiş bir araştırmacı, bir kültür tarihçisi, Kafka, Proust ve Leskov gibi yazarlar hakkında yazmış bir eleştirmen, kimi düşünceleri felsefi düzeyde aktaran bir düşünür olarak görebiliriz. O'nun 
yazıyı gündelik yaşamını idame ettirmek için kazancının kaynağı olarak kullanan birisi olduğunu düşünürsek yazı repertuarının geniş olmasını garipsememek gerekir. Benjamin, bir şeyler hakkında yazan birisini, bir araştırmacının yazısını karşımıza getirmez. O'nun yazısı deneyim üzerine çeşitli düşüncelerinin toplamıdır. Belki de O'nun gündemde kalmasının nedeni budur. Kalem oynattığı konular hakkında parlak düşünceler ve çözümlemeler üretmesinden başka bir yazı üretmesi ve bunu deneyimi kurtarma arzusunu gerçekleştirmeye çalışmak için kullanmış olması Benjamin'in önemi konusunda fikir vermektedir.

Deneyim, Benjamin için artık aktarılamayan özelliktedir (Benjamin, 2001: 78). Ortada bir sorun vardır. Deneyim aktarılamaz haldedir. Doğrusu aktarılan, deneyim değildir. Başka bir şeydir. "Deneyim değer kaybetti" diye yazarken, onun araçsallaşmaya mahkum olduğunu, "sanki kesinlikle bizim olan, kaybetmeyeceğimizden emin olduğumuz melekelerimizden biri (...) elimizden alınmış" demektedir. Bu meleke "deneyimlerimizi paylaşma yeteneğimiz"dir (Benjamin, 2001: 77). Bu değersizleştirmeden çok öte insan varoluşunun eksiltilmesi, başkalaştırılmasıdır. Modernizm deneyimin "metodik yıkımı"dır (Benjamin akt. Jay, 2012: 387). Bu yıkımın büyüsü "insanların yeni bir deneyimin özlemini" duymasını engellemesidir. $\mathrm{Bu}$ öyle bir ideolojik perdelemedir ki "insanların özledikleri deneyimlerinden kurtulmak" tır (Benjamin, 2016: 30).

Modernler için deneyim kaybının önemi nostaljici tutumunun o kadar kolay algılayabileceği bir şey değildir. Romantiklerin 'kayıp' konusunda derin kaygıları melankolik ruh halleriyle görünürlük kazanmıştır. Kaybedilen bir özün, insana dair olan ortaklıkların, organikliğin ortada görünmemesi onlar için derin bir hüznün nedeni olmuştur. Sebepsiz mutsuzluk, karanlık ruh halleri sürekli bir arayış ve kökene dönüş istekleri günümüzde anlamsız görülebilir. İlk bakışla Romantizm'in muhafazakâr tavrın özlemlerine dair bir şeyler söylemek günümüz muhafazakârlığın tarih yapıcı, nostaljici özlemleri romantiklerle benzerlikler göstermektedir. Bu geçmişte de böyledir (Jay, 2012: 390). Bugünün muhafazakâr tutumunun geçmiş özlemi, kaybedilmiş deneyimin kendisine değil, tarihin dondurulmuş bir dönemine, altın çağa karşı olan derin özlemdir. Bu tutumun ise modern kültürden günümüze faşizmle buluşması kaçınılmazdır. Özlenen altın çağ ile şimdi geçmişe bağlanılacak, şimdi kitlenecek ve onun hareketini engelleyecektir. Oysa Benjamin gibi bir romantik için özlem deneyimin kendisidir. Deneyimle insanın hakikati yaşamasıdır. Ancak Benjamin, ne yukarıda anılan günümüz muhafazakâr geçmiş özlemindeki gibi bir altın çağcıdır, ne de günümüz New Age tarzı tinselcilerine benzemektedir. Tarihin ilerleme olarak görüldüğü bu hareketlere karşılık ilerleme Benjamin için felaket ile ilişkilidir (Benjamin, 2007: 193).

Benjamin nostaljicidir. Özlenen zamanların idealize edilişi O'nun ilgisini çekmemektedir. İdealize hal, donuk bir fotoğraf imgesidir. Benjamin tersine, hareketli bir kültürel varoluşu yazmıştır. Tutumu özne-nesne ikililiğinin aralarındaki mesafenin meydana getirdiği krizler hakkındadır. Benjamin de pek çok modernite eleştirmeni gibi söz konusu mesafenin hakikate dair olmasıyla derin bir yara meydana geldiğini düşünmüştür. Bu derin yaranın sonuçlarını da canlı kanlı yaşamaya devam etmiştir.

Labirentimsi Paris caddelerini arşivde dolaşırken dışarıda Nazi rejimi tüm Avrupa'ya kıymaktaydı. İlerlemenin, teknikleşmenin, adem-i merkeziyetçiliğin, bilimselciliğin, kötü bir 
romantizm olarak nostaljici tutumun ürünü olan faşizmin meydana getirdiği deneyim dünyası kapitalizmin eseriydi. Son yıllarını kaçak bir şekilde geçim sıkıntısıyla geçiren, tek becerisi yazmak olan ve yakın dostları da dahil yazdıkları konusunda yalnız bırakılmış birisinin elinde kalanın sadece dil olduğu görülmektedir. Kaçak bir bedenin yıkılmaya başlamış şimdiki zaman içinde deneyimleyeceği korku ve tedirginlik karşısında dil bir başka duruma açılışın imkânı olmuştur.

Benjamin, "Gelecekteki Felsefenin Programı Üzerine"de (1918), "günümüzden ve gelecek hakkındaki beklentilerimizden en derin imaları çıkartmak"tan ve bunları Kant felsefesiyle ilişkilendirerek bilgiye dönüştürmekten bahsetmektedir (Benjamin, 2005: 125). Bu düşüncesi Benjamin'i boş bir nostaljici olarak görmeyi engellediği gibi yaşamı boyunca önem verdiği bilgi ve eylem prosedürünün de özeti olarak okunabilir. Kant sisteminde deneyimin sorun edildiği, O'nun deneyimi matematiksel ilkelerle tanımladığını yazan Benjamin bunu nedensiz ve değeri olmayan bir deneyim olarak görür (Benjamin, 2005: 126). O'na göre Kant içi boş bir deneyim tanımı yapmıştır (Benjamin, 2005: 127). Yeni-Kantçı deneyim izahının mekanik-matematiksel tanımlamaları karşısında da Kant'taki eksikliği çözüm olarak

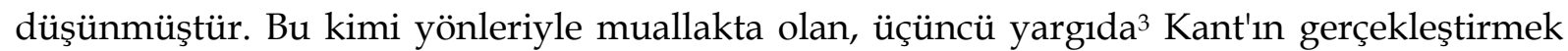
istediği bilgi kavramının "bilginin dilsel doğası üzerine" düşünümüyle gerçekleştirilebileceğidir (Benjamin, 2005: 133). Deneyim mekaniğin alanlarıyla ilişkilendirilmesinin yanında bazı alanlar (geometri, psikoloji, betimleyici doğa bilimi) ve de dilbilgisiyle ele alınmalıdır (Benjamin, 2005: 132).

Dil, bir araç olarak anlam taşıma görevindedir. Ancak bu araç modern kültürde gücünü yitirmiştir. Dil araçsallaşarak ketlemeye başlamıştır. Kapitalist düzenin araçsallaştırıcı gücünün gölgesinde Marksist yanlış bilinç olarak ideolojinin, yapmak ve bilmemek arasındaki dengesizlikte bilinç dönüşümün gerekliliği dil içinde mana kazanacaktır. Ancak ne Kant, ne de Marx dil üzerine düşünmenin yüzyılındaydılar. Benjamin aynı düşünce kuşağında olduğu Heidegger, Wittgenstein, Saussure gibi isimlerle dil üzerinden bir düşünce ve yöntem geliştirmeyi önemli görmüştür.

"Kendi Başına Dil ve İnsan Dili" (1916) makalesinde bu görülmektedir. Bu makale de Benjamin'in çok yönlü ya da çok başlılığını4 göstermektedir. Bu makalenin "iki kaynağı vardır. Bunlardan birincisi kabala ya da Yahudi mistizmi [tinsel öz ifadesi onunla ilgilidir]. Özellikle de onun içinde dilin anlamı. İkinci olarak da, Alman idealizmindeki deha kavramıdır" (Dellaloğlu, 2012: 45,47). Benjamin dili tanımlarken zamanına kadar çok bilinen temel problemi terk etmeyi önerir. Ayrım tinsel öz ile dilsel öz arasındadır. Tinsel öz, dilde ifade edilen olarak düşünülmüştür. Benjamin ise onun "dilde" ifade edildiğini yazar.

Tinsel öz kendisini dil aracıliğıyla değil, dilde iletir; bu da onun dilsel öz ile dışsal olarak özdeş olmadığı anlamına gelir. Tinsel öz dilsel öz ile yalnızca iletilebilir olduğu ölçüde özdeştir. Tinsel özde iletilebilir olan, onun dilsel özüdür. O halde dil, şeylere özgü dilsel

\footnotetext{
3 "Yargigücünün Eleştirisi” (2006)

${ }^{4}$ Benjamin'in bu çok yüzlülüğü, bir Janus benzetmesiyle, yarı mistik yarı Marksist ve diğer yüzlerine dair açılklamalar için Recep Alpyağıl "Benjamin'in Mistisimine 'Üç Yönlü Yol' " adlı çalışmasına bakılabilir (2007: 201-209).
} 
özü iletir; tinsel özü ise yalnızca dolaysız olarak özde içerildiği, iletilebilir olduğu ölçüde iletir (Benjamin, 2001: 170).

Tinsel olan tümüyle dilin içinde iletilemez, onun dile uygun yönü iletilebilir. Tinsel olan dilde iletilirken cisimleşmektedir. Tinsel olanın maddileşmesi onun üretimidir. Dil, insanın adlandırabilmesiyle, özün (essentia) adlandırmasıyla işler. Sözcük ile öz bütünleşik ve birbirlerini sarmazlar (Armaner, 2007: 142). Dili kullanan üretici konumdadır ve dünya içinde atılmışlı̆̆ını kapitalizmin güçleriyle yıkıma uğramış olduğu kültürde bir şeyleri toparlaması için işaretlerin peşine düşmesi gerekmektedir.

Benjamin, "Sürrealizm: Avrupalı Aydının Son Fotoğrafı"nda (1929) "her şeyden önce imge ve dil" diye yazmaktadır: "Sesle imge, imgeyle ses, "anlam" denen beş para etmez şeye hiç alan birakmayacak kadar müthiş bir uyum ve otomatik bir kesinlikle birbirine kenetlendiğinde, dil işte o zaman kendisi olacaktır" (Benjamin 2011: 53). Dil konusunda zaman içinde bir fikir değişimi olduğunu düşünmek mümkün. Ancak Benjamin ilk dönemlerinde de anlamın kesinliğinden çok dilin deneyimi işaretlemesi ve üretmesine değer vermekteydi. Anlamın kesinliği Benjamin'in ilgilendiği bir konu değildir. Dili harekete geçirecek bir etkinin içinde onun aktarımı ve onun yaşanmasıyla ilgilenmekteydi. Benjamin'in düşüncesinde avangard yazının dil üzerine deneyselliğinin etkisi aynı zamanda aura ${ }^{5}$ düşüncesinin parçalarını da oluşturmaktadır: "İster fütürizm, ister dadaizm, ister sürrealizm adını alsın, son on beş yılın tüm avangard edebiyatında görülen tutkulu ses ve yazı oyunlarını, sanatsal oyalanmalar olarak değil, sözcüklerle girişilen büyülü deneyler olarak görmek gerek" (Benjamin, 2011: 59).

Her şeyin kaynadığı bir anın içinde öznenin dildeki üretimi, onun kendisini kaybetmesi, esrarın içinde yitip gitmesidir. Kayıp, bir yitiriliş olarak, kendisini var eden koşullarla yüzleşmeyi şart koşmaktadır. Avangardın büyülü ses ve imgelerinin, dil oyunlarının amacı aslında şeyleşme ve yabancılaşmanın, modern kültürün şok aygıtlarının içine yuvalanmış olan deneyimin imkanlarını yaşamaktır. Benjamin burada tarihsel materyalist ve Marksist tavrını göstermektedir: Böyle bir deneyim ile dünyayı dönüştürmek, devrimci deneyimi üretmek mümkün müdür?

Benjamin'in metodu ya da yaşamı bunun üzerine kuruludur. Deneyimi üretmek, aktarmak, onun dönüştürücü gücünü fark etmek, yaşamak... Bu düşüncelerin sahibinin iki dünya savaşı arasında etkin bir yazı geçmişi olduğunu, insan soyunun deneyim olarak ölüm ve kıyım ile tanıştığ zamanların tanıdığı ve kaçağı olduğu düşünülmeden edilemez. Avrupa medeniyetinin yüzlerce yıldır meydana getirdiği kültürel katmanların bir bir yıkıldığı, çok değil on dokuzuncu yüzyılda değerlerin değiştirilmesi ve üzerine düşünülmesi diyerek ortaya çıkan bir başka Alman Nietzsche'nin ön görüleri ve tahlilleri, yine bir diğer Alman Marx'ın müjdeler gibi yazdığ1 yaklaşan hayalet komünizmin musallat olacağ1 bir gelecek içinde Avrupa, kapitalizmin teknikleştirme gücünün ve küreselleşmesinin karşılığı olarak birinci dünya savaşını ve tüm değerlerin yıkımı, arzulanan geleceğin felaket ile yer değiştirmesi

\footnotetext{
${ }^{5}$ Bu kelime hale olarak da çevrilmektedir. Yaygın kullanımı da söz konusudur. Ancak bu yazıda aura kelimesi tercih edilmiştir.
} 
olarak ikinci dünya savaşını yaşayacaktır. Sokaklar ve caddeler tehlikeli, hele hele Yahudi ve sol görüşleri olan birisi için daha da sıkıntılı olacaktıŕ. İşte Benjamin'in dünyası.

Ne olursa olsun Benjamin, şimdi içinde özgür bir mekân ve zaman deneyiminde değildir. O geçmişe aittir. Geçmişin izlerinin peşinde olan Benjamin, bellek imgeleriyle işe başlamıştır. Bu imgeler güzelliğin, insanın şimdi içinde mücadelesinin ve yaratıcıllğının kaynağıdır. Benjamin için deneyim bir mücadele olarak düşünülmesine sebep de budur zaten (Jay, 2012: 391). Deneyim güçlü bir değerler dünyasının icadıdır. Çocukluk anıları, akla takılan anlar, anlamsız isimler ve kelimeler, onların kendisinde uyandırdıkları, tüm bunlar Benjamin'in deneyimi kurtarma çabasında saklı bir kişisel olanı, kendisini kurtarma derdinin bu değerler dünyasına olan ilginin işaretleridir (Jay, 2012: 387,389).

Benjamin'in gündelik hayat üzerine incelemeleri, görüngülerin üzerinde hüküm süren kapitalist sistemin incelenmesine dayalıdır. İncelemeleri onlardaki iktidarın silinerek saflaştırılması şeklinde işlememektedir. Bu görüngüler, söz konusu sistem tarafından varlıklarını kazanmışlardır. Asıl mesele de onların kendi içlerindeki potansiyelleri görebilmektir. Bu Sigmund Freud'un psikanalizini akla getirmektedir. Her iki düşünür de benzer bir yorumlamacı anlayışa sahiptirler.

(...) Freud ruhsal yaşamı günlük yaşamdaki konuşma ve jestlerin yorumlanabilir içeriği ile ilişkili olarak yeniden biçimlendiriyorsa, Benjamin de gündelik görünüşler ve metanın 'gizli konuşması' ile ilişkili olarak kültürel kuramı yeniden biçimlendirmektedir (...) Semptomun görünürdeki anlamsızlığına bir tarih verilmektedir. Ve nasıl konuşmatedavisi travmanın anısının sürekli olarak hatırlatılarak iptal edilmesini ve bu tarihin kelimelere dökülmesini içeriyorsa, Benjamin'in günlük yaşamı yabancılaştırılmış semptomlar ve arzu göstergelerinin bir alanı olarak anlaması da benzer şekilde göstergenin yeniden-sunulmasının yorumsal 'şok'una 'doğrudan olanın' somutlaştırılmış 'yeniden üretimi'ni parçalama ve günlük yaşamı tarihsel bir perspektifine yeniden ele alma gücü vermektedir. Hem Freud hem de Benjamin, tarihsel yaşamın içerikleri ile hatırlama ve temsil süreçleri arasındaki asimetriyi vurgulamaktadır (Roberts, 2013: 84,85).

Benjamin'in incelemeleri olguların tarihsel görünümleri üzerinedir. $\mathrm{Bu}$ onları cisimleştiren koşulların, onlar üstünde meydana getirdiği gerilimlerin ele alınmasıdır. Onlardaki gerilimler, onların koşullarının şartlanmasından kaçak hatlar meydana getirmesiyle başka bir görünüme neden olurlar. Benjamin'in ilgilendiği de bu kaçak hatların devrimci deneyimleridir. Bu yüzden O'nun yazısı tipler ve karakterlerle doludur. Bunlar gerçek olduğu kadar Benjamin'in bu bakış açısının üretimleridir. Kendi üzerlerinden geçen bir sistemi ondan kaçış yollarını barındırmalarıyla ilgiye değerdirler. Çünkü bu kaçışlar yeni deneyimler anlamina gelmektedir.

\section{Çocuk}

Çocuk, modern karakterlerden birisidir. Hatta o ilk modernlerdendir. Çocuk modernliğin ruhuna özgüdür. Modern bilimselcilik için çocukluk insanlığın tarihsel

${ }^{6} 1933$ tarihiyle birlikte Benjamin Nazi rejiminden dolayı çok zor bir hayat geçirmiştir. 
serüveninin ilk evrelerini anlamak adına analoji işlevi görmüştür. İnsan modernlik ve aydınlanma ile çocukluğunu gerilerde bırakmıştır. Çocukluk terk edilmesi gereken, eksikleri olan insan imgesidir. Çocukluğun kökenselliğinin Freud'un psikanalizindeki yorumu çocuğun ruhsal süreci bir dizi insanlık tarihi kalıntısının izleriyle donatmıştır. Evrimsel anlamda çocuk, insanlığın en eski kalıntılarının yuvasıdır. İnsanın yaşı ilerledikçe unutulacak olan bir odadır burası. Bu oda, ilk insanın karanlık korkusundan, yuva özlemi çeken, baba düşmanı olan, hayvani vahşiliği ve kuralsızlığı içinde barındıran ilkel insan imgesini barındırmaktadır. İkinci olarak çocukluğun ruhsal süreçleri unutulmuş olan otantik bir benliğin, ilgi çekici bu vahşinin, saf bir zihinselliğin, özne-nesne ayrımının öncesine dair bir hatırlama sunmaktadır. Çocukluk, ilkelliği ve kuralsızlığıyla, odasından vahşi bir ağlama ile çıkacak bir başkalıktır. Aynı zamanda o psikanalizin normalleştirici konuşma küründe, huzura erdirici hakikatleri elinde barındırmaktadır. Nietzsche'nin Zerdüşt'ünün vaat ettiği çocukluğa doğru bir dönüş7, insanın unuttuğu derinliğe karşı bir dönüşü, geleceğin insanı üstinsanın örneği olarak karşımıza çıkartmaktadır. Çocukluk, Marx'ı izleyenlerin komünal hayatın kuralsız ve paylaşımcı, eşitliğinde anlamı ilkel olana dair romantik bir istençtir. Çocuk, geleceğin insanı, geçmişin izinin bir proje olarak ya da üst bir sözün hatırlattığ unutulmuşların sözcüsü olarak modern kültürde bu şekillerde varlık kazanmıştır.

Çocukluğa dönüş, modern kültürün bir özelliğiyse bunun en çarpıcı örneği yaratıcılığın, yüzlerce yıldır antik sanat kurallarının yüceltildiği, plastik sanatlarda hakim olan Rönesans kültürünün birikiminin çocuksu vahşiliğe yerini bırakmasıdır. İzlenimci, fovist veya dışavurumcu resmin kaba fırça vuruşları, renk armonilerindeki vahşilik, gözün alabildiğince düzenli sürüşlerinde bile çocuksu yere dökmenin görülebileceği eserler yüzlerce yıldır süregelen mimesis kategorisinin, eserin doğanın yetkin taklidi olmasının terk edilmesidir. Tüm evrenin taklitte saklı bilgisi karşısında, doğaya koşut giden insanın kendi özgelişiminde önemli olan bu hali terk ederek yerine çocuksuluğu geçirmek, modern kültürün bir figürü olarak çocuğun bir başka anlamıdır. Bu bir saflaşmadır ${ }^{8}$. Doğaya yönelimin kendiliğindenliğinin, hülyalı bir içe dalışın, tüm dünyanın koca bir resimler yığını, sanki bitmeyecek bir imgeler toplamı gibi kayması sanatçının atölyesinde karşımıza çıkmaktadır.

Benjamin mistik yalnızlık ve dünyadan elini ayağını çekmek gibi yanılgılara sürklenmemişse bunun nedeninin çocukluk anılarının deneyim konusunda ilham verici olmasıdır denilebilir. İlham öylesine bir etki değildir. Çocukluğun kendine ait deneyimleme zenginliğinin yetişkin haline hissettirdiği köke dönüş isteğidir. Proust üzerine yazısında Benjamin'in çocukların sadece bu dünyaya ait değil, düşler dünyasına da ait olduklarını, bu dünyayı çok iyi tanıdıklarını söylemesindeki gibi. Bir şey kendi anlamıyla, düşlerdeki anlamılla ve de çocuğun kendisine biçeceği bir başka anlamıyla karşılık bulmaktadır

\footnotetext{
7 "Böyle Buyurdu Zerdüşt"te Zerdüşt, insanlara sizlere deveden insana ve oradan nasıl çocuk olunması gerektiğini anlatacağım der (Nietzsche, 2001).

${ }^{8}$ Benjamin, sanatın bu eğiliminin "çağın yalın ve çıplak insanına yönelmek, dönemin yeni doğmuş bir çocuk gibi kirli kundakları içinde emekleyen insanına eğlemek istiyorlardı" diye yorumlar (Benjamin, 2016: 28).
} 
(Benjamin, 2004: 105). Bu yüzden çocuğun deneyiminin ilgi çekiciliği sanatkarca bir tutumun kendiliğindenliğini, dünyanın anlamını saf bir tutumla yakalayabilmesinden gelmektedir.

[Çocuklar] duygularını işe karıştırmadan bakarlar. Ruhani bir şeydir bu: Gökkuşağı, nezih bir soyutlamaya değil, sanattaki bir yaşama gönderme yapar. Sanat düzlemi cennetimsidir, çünkü deneyim nesnesinde stnırlarn -heyecandan- çözülmesi gibi bir düşünce yoktur burada. Aksine dünya bir özdeşlik, masumiyet ve uyum halindeki renklerle doludur. Çocuklar utanmak nedir bilmezler, zira düşünmeyip görürler sadece (Benjamin, akt. Jay, 2012: 393).

Benjamin'in deneyim düşüncesinde 'görmek' önemli imkanlara sahiptir. Çocuksu görmek, nesne ve özne ayrımının olmadığı, her şeyin birbiri içine geçtiği bir evreni deneyimlemektir. Benjamin'in bir yerde söylediği gibi "modern insanın sezgi dünyası, eski halklarda yaygın olan büyülü göndermelerden ve benzeşimlerden geriye kalan pek az şey içerir" (Benjamin, 1998: 12). Çocuk, güçlü bir sezgisellik, Benjamin'in en önemli yeti olarak gördüğü öykünme yetisine sahiptir. Görme ve çocuk ya da çocuksu görme, daha sonraları Benjamin'in, bir çağın ruhunu yansıttığını düşündüğü şair Baudelaire'in hasta yatağından kalkmış ve nekahat evresinde kenti dolaşan, her gördüğünü belleğine kazıyan flaneur imgesinde bir başka örneğini bulacaktır (Baudelaire, 2003: 95-103). Ressam C. G., Paris gezintilerinin ardından akşamları çekildiği odasında elinde mürekkebiyle belleğindeki gelip geçici imgeleri resmetmektedir. İşte çocuksu bir edim. Görmenin büyüleyici deneyimi, hatırlamanın yeniden düzenleyen gücü. Anılar sadece hatırlanmazlar, üretilebilirler de. "Hatırlanan olaysa sınırsızdır" diye yazar Benjamin, onun yaşanmış olay ile farkını ortaya koyarken, "çünkü kendinden önce ve kendinden sonra olup biten herşey için anahtardır sadece" (Benjamin, 2004: 102).

Deneyime karşı derin ilgi, insan varoluşunun otantikliğinin kaybına karşı duyulan romantik melankoliyi göze getirmektedir. Benjamin de buna sahiptir. Bu yüzden pek çok modern gibi hatırlamayı devreye sokmuştur.

Anımsamak Benjamin için bir mücadele demektir; bir süreç ya da çizgisel gelişim değil, yanıp sönen imgelerden oluşmuş bir dizi. Anımsama çabası ve anıların aldığı biçim. Benjamin' in çevirisini yaptı̆̆ Proust ile uyumlu ve kenetlenmiş olduğunu, öte yandan Freud ile daha dolaylı bir bağlantı kurduğunu gösterir. Anının çizgisel olmaması [nonlinearity] ve yeniden üretilmiş imgenin anının suflörü olarak bulunabilirliği, Benjamin'in tarih algılaması ve Pasagenwerk' teki (Pasajlar' daki) (...) geliştirmeye çalıştı̆̆ı yazı metodu için can alıcı öneme sahip olduğunu göstermişlerdir (McRobbie, 1999: 149).

Benjamin, Proust ve Freud. Üçü de hatırlamanın deneyimini, sadece bellek imgesinin anımsattığı anın kendisi olarak değil, şimdiyi kuracak bir patlayıcı güç ile benliği sarsan etki şeklinde düşünmeleriyle ortaktırlar. Bellek üçünde de tazelenmez. Kekeler. Dil içinde yeni yollar arar. Tarih birden başka türlü okunmaya başlar, geçmiş kokular ve tatlar içinde başkalarılla başka anlamlara bürünür, benlik unutulmayacak anıların zulmedici ikamelerin içinde bulunduğu sahnede kendisi olur. Üç figürde günümüz unutma toplumlarını öngörür şekilde elde kalanı hafızayı öne sürmüşlerdir. 


\section{Hikâye Anlatıcısı}

Bir zamana ait hikâye anlatıcıları deneyimi aktarma işini becerebilen ustalardır. Modern kültürde aktarılamayan, katılaşmış bir deneyimler yı̆̆ıntısına karşılık hikâye anlatıcılarının varlıkları topluluğun varoluşu açısından değerli bir anlama sahiptir. Hikâye anlatıcısı atomize olmuş modern bireyi bir araya getirebilecek olanağı içinde barındırmaktadır. Kant'daki 'ortak duyu' düşüncesi gibi. Ortak duyu, yargılarımda bir başkasının benim gibi düşünebileceğini önceden biliyor olmam ve aslında benim de onun gibi düşünüyor olduğumu bilmem ile ilgilidir (Kant, 2006: 93,94). 'Ortak duyu' sadece güzele dair bir ortaklığı değil, topluluğun bir aradalığını organik şekilde kurmanın imkânıdır. Hikâye anlatıcısı bir arada olmanın imkânını deneyimi aktarabilmesiyle mümkün kılacaktır.

Benjamin, Kant'ın bu düşüncesini, toplumsal yaşantının bir ürünü olan hikâye anlatımında yakalar. Hatta Benjamin Kant'ın sadece düşünsel boyutta dile getirdiği bu düşünce biçimine, eylem boyutunu da katarak onu daha da ileri bir noktaya çeker. Başka bir deyişle hikâye anlatımı hem düşünümde ortaklı̆̆a hem de eylemde ortaklığa kapı açar. Bu açıdan Benjamin'in kaybolan insanlık idesini yeniden tesis etmek için kullandiğı hikâye anlatıcısı, bir yandan politik bir bütünleşmeyi yani "genişletilmiş yaşam deneyimi"ni, diğer yandan da estetik bir bütünleşmeyi yani "genişletilmiş bir zihni" içerir (Sütçü, 2013: $80,81)$.

Hikâye anlatıcılarının elinde anlatı bitmediği gibi uzaklarda olanlar yaklaştırma gücüne sahiptir. Anlatılanlar bilgi verici, öğüt niteliğindedirler. Anlatılanlar okuyucusu veya dinleyicisi için zorla kabul edilmesi gereken ilgi çekici seyirlikler değildirler. Anlatılanlara eklenecek bir şeyler hep vardır (Benjamin, 2001: 82). Hikâye anlatıcısının anlattıklarının değeri anlatının deneyimlenmesinde onun tek başına olmamasıdır. Dil dinleyiciyi de kapar, olaylar anlatıldığı an yeniden yaşanan bir dizi olayı sunarken, dinleyici büyüleyici olana soruları veya yorumlamalariyla eklemelerde bulunur.

Deneyimin dilsel ifadesinde dinleyicinin üretici konumu hikâyenin sürdürülebilir olması ile ilgilidir. Döngüsel ve tekrarlara dayalı bir anlatı modern enformasyon iletişiminin demokrasi yanılsamasıyla unutturulmuştur. Enformasyonun zamansallığı onun yeni olması, görünüp yitmesiyle ilgili olmuştur. Enformasyonda dinleyici sürekli dikkat eksilmesine neden olan yinelenen ayrıntılara boğulmaktadır. Bu yüzden enformasyon değerlerle ilişkisi olmayan bir iletişim tarzıdır. Böylelikle enformasyon meydana gelen felaketleri aktarmaz. Kaybı hissettirmez. Kendi varoluşu bu kaybın semptomu olsa bile.

(...) Leskov bunda ustadır ("Aldatma" ve "Beyaz Kartal" gibi hikâyeler buna örnektir). Olağanüstü ve mucizevi şeyleri bütün ayrıntılarıla anlatır, ama okuru hiçbir zaman olayların arkasındaki psikolojik bağı kabul etmeye zorlamaz. Olayları kendi anladiğı biçimde yorumlamak okura kalmıştır; böylece anlatı, enformasyonun yoksun olduğu genişliğe ulaşır (Benjamin, 2001: 82).

Enformasyon karşıtı bir dil imkânı olarak hikâye, Benjamin' in tedavi edici anlatı olarak eski halk inanışlarına kadar uzanmaktadır. Hastanın tedavisinin, anlatılan hikâye yardımıyla gerçekleştirilmesi hikayenin toplumdaki ortaklığı sağladığını gösteren bir sahnedir. Hastanın 
hekime hikaye anlatması ve hekimin hastasıyla iletişimi acının anlatı karşısında dirençsizleştirilmesi enformasyonun gerçekleştiremeyeceği bir şeydir (Benjamin, 2016: 73).

Kitle iletişim aygıtlarının kültürü sardığı ve onu üreten konuma geldiği bir zamanda Benjamin 1927-33 yılları arasında radyo programları hazırlamıştır. Entelektüel kariyerinin ilk evrelerinde kültürel derinliklerin peşindeki Benjamin, bu evrede yüzeyde gezinen olgulardaki parıltıların, onlardaki kuşatıcı auratik gizemselliğin devrimci bir enerjiye dönüştürülmesiyle uğraşmaktadır. Bu programlar da böyle bir görüşün izlerini taşımaktadır.

\section{(...) programlar otoriter bir sesten tümüyle azadedir. Didaktik mesaj daha çok tarihsel anekdotlardan, serüven hikâyelerinden ve edebi simaların biyografilerinden çaba göstermeksizin, yaratıcı bir şekilde çıkar. Hikâye anlatıcısı Benjamin, çocuklarla -ve ayrıca edebiyatın geleneksel olarak entelektüel küçümseme dersi olduğu alt sinfflarla- işbirliği içinde görünür (Buck-Morss, 2015: 53).}

Benjamin'in sanat düşüncelerinin ilk görünümlerine rastladığımız bu evrenin Benjamin'in aynı zamanda kaybedilen deneyim aktarımının, hikâye anlatıcısının kültürel otantikliği sağlayan sesini ele geçirmeye, onu devam ettirmeye çalışmasına esaslı bir örnek olduğu kolaylıkla görülebilir.

\section{Koleksiyoncu}

Koleksiyoncu kimdir? Meta fetişizminin olduğu bir zamanda onun kurtarıcı bir figür olması ne kadar beklenebilir? "Her tutku, kaosa dokunur" diye yazar Benjamin (Benjamin, 2005: 151). Bu sözün koleksiyoncuyu açıkladı̆̆ını söylemek gerekiyor. Kaos, anılardır. Biriktirme anılara dairdir, ona "dokunmaktır" (Benjamin, 2005: 151). "Kütüphanemi Yerleştirirken" (1931) denemesinin bitişinde yazdığı gibi: "Benim için hakiki bir koleksiyoncunun nesnelerle kurabileceği en mahrem ilişki mülkiyet ilişkisidir. Nesneler onda değil, o nesnelerde yaşar. Ben de zaten onun kitaplardan oluşan evini inşa ettim sizler için ve şimdi o bu evin içinde, hak ettiği gibi, yitip gidiyor" (Benjamin, 2005: 158).

Koleksiyoncunun geçmişe olan bağı, nesneleriyle olan tutkulu ilişkisi, onların içerdikleriyle ilgili değil, onların tınılarıyla ilgilidir. "Mistik mülkiyet", nesnelerin kullanımlarıyla ilgili olmayan bir ilişkidir. Nesne, içeriksizliğiyle kendi başına yaşadığı süreci, kendi tarihini üzerinde taşımasıyla Benjamin'in denemesinde karşılığını bulmaktadır.. Koleksiyoncu tek bir nesneyle işe başlamaz, diğerlerini de ekler. Kapitalist tüketimciliğin palazlandığı bir zamanda nesnelerin birbirleriyle olan işe yararlılık ilkesinden ziyade doğaüstü gönderim ilişkisi, koleksiyoncunun modern tiplerden biri olarak görülmesine neden olmaktadır. Ancak o eski bir tiptir de. Modern izleyicinin göremediğini görendir. Bir büyücüdür o. "Tekil nesneyi büyülü bir çekim alanına" hapseder (Benjamin, 2005: 152). Kendini yitiren bu büyücü nesnelerde geçmişin izlerini, onların hikâyesini görür. Her türden insan, nesnenin gezindiği mekânlar zaman boyunca üstünde birikmiş olan işaretler, her birinin auratik etkisi, onu okuma gücüne sahip koleksiyoncu, nesneye ait olandan çok zamanın ondaki varlığını deneyimlemeyi arzulamaktadır. 
Deneyimin aktarılması sadece özneler arası bir iletişim değildir. Aktarım, deneyimin dilsel ifadesinde saklı olan üretiminde, deneyimin kendisini yaşamak, ondaki her şeyle bir arada olmaktır. Nesnelerin deneyimi böyledir (Özbek, 2000: 114). Koleksiyoncu meta deneyiminin iki yönlülüğüne örnektir. Kendi dünyasında bir modern tip olarak diğerlerine benzemek zorunda kalmıştır. Ancak diğerleri gibi, köksüzleşen, enformatik bir iletişim dünyasında araçsallaşan bir yaşantının bireyi olmanın yanında onlardan ayrılarak, kendi deneyim dünyasına, koleksiyon nesnelerinin geçmişten gelen izlerinin peşine düşmüştür.

Koleksiyoncunun stratejisi, nesnesine karşı derin ilgisinin, diğerleriyle rekabet halinde olmasıdır. O kendinde kendisini biriktirmeyi istemektedir. Geçmişin izlerinin, nesnenin nadirliğinin kendisinde uyandırdığ 1 derin ilginin peşindedir. Bir başkası sadece zamanın içinde kalan bir iz olarak ezoterik bir dilmiş gibi kendisine heyecan vermektedir. Böylesi bir heyecan kendisine dönük bir deneyimdir. Koleksiyoncu hikâye anlatıcısı gibi değildir. O bir çocuk gibi, fetişleşen nesnede kendi huzurunu bulan derin bir bakışın sahibidir.

Benjamin, özgür tipler meydana getirmemiştir. O'nun tipleri dışarıda, zamanın ilerisinde bizleri bekleyen birer ide değildirler. Geleceğin komünist rejiminde işçi sınıfının tarihin ilerisinde beklemesi gibi Benjamin'in karakterleri geleceğe atılmamışlardır. Onlar kanlı canlı ve en önemlisi modern kültürün diyalektiğini yaşayan, modern kültürün ürettiği tiplerdir. Her biri deneyim ve imge üzerine bir şey söylerken, kendi şimdimize doğru yol aldığımızda, onların yansılarının hala sürdüğünü görebiliriz. Bunlardan bir tanesi de flaneur'dür9.

\section{Flaneur'un Modernlik Deneyimleri}

"Pasajlar" projesi Benjamin'in magnum opus'u olma iddiasıyla değerli, bitmemişliğiyle gizemli ve üretilebilir bir Benjamin portresi için ideal bir yığın görevi görmektedir. Bir kültür tarihi olarak anlamlı, yöntem olarak ise yenilikçidir. Adorno'nun "felsefe, gerçeküstücü hale geliyor" dediği bu yöntem, bütüne ulaşmak isteyen bir tarihçi ve araştırmacı tutumu yerine "yalnızca malzemenin şoke edici montajından" yapının "doğmasını beklemektedir" (Adorno, akt. Frisby, 2012: 239).

Benjamin, fragmanların bir araya serpildiği ve kendiliğinden bir araya geldiği, tarihsel ve yöntemsel zorunlulukların olmadığı bir kolaj metin oluşturma amacındaydı. Çalışmasına 'edebi montaj' adını takmıştı. Montaj, daha sonraları film aygıtında da görebileceğimiz gibi hem kapitalist fabrikasyonun anlamı hem de avangard sanatların kullandığı bir yöntem olarak ikili bir anlam taşımaktadır. Montaj hattına giren her fragmanın bir değeri var mıdır, bu bile şüphelidir. "Yalnızca artıklar, yalnızca çöp ki onları tarif etmeyip yalnızca sergileyeceğim" diye yazmıştır (Benjamin, akt. Frisby, 2012: 239).

${ }^{9}$ Flaneur kelimesi aylak kelimesiyle Türkçe'ye çevrilebilir. Ancak kelime özel bir anlam ve tarihsel referansları nedeniyle bu hali ile kullanılmıştır. 
Kültürel dışavurumlar, tüm görüngüler, toplumun örgütlenişi Benjamin için "düşsel imgeler, fantazmagoryalardır10; çünkü onlarda eski ve yeni, ayrımsız bir biçimde karışmış" görünmektedir (Witte, 2002: 144). Fantazmagoryalar aldatıcılıkları ve metanın auratik büyüleyiciliğiyle Paris'in gündelik ve sıradan görsel deneyimini anlatırlar. Kapitalizm, Weber'in iddiasının tersine ${ }^{11}$, Benjamin için yeni mitler meydana getirmiştir (Buck-Morss, 2015: 279). Fantazmagoryalar da bu mitlerin atmosferidir. "Pasajlar" da kitle kültüründeki mitlerin silinmesi ve temizlenmesini amaçlayan şeyleşme ve yabancılaşmadan kaçmaktansa ona bir dalış eylemi önermektedir.

Gelgelelim Benjamin "rüya âlemlerinde" kalmak yerine, "tarih âlemindeki 'mitoloji'nin imhası" yoluyla "uyanış burcu" yaratmayı tercih etmişti. Pasajlar üzerine ilk düşüncelerinde bile, (tek yönlü Yol'da bulunan kimi Denkbilder [zihinsel imgelerle] açıklanmış olan) metalardan oluşan rüya âlemi fantazmagoryasının, meta denen gizemin kilidinin açılmasını, yeni'nin hep-aynı diye ilan edilmesidir. On dokuzuncu yüzyıl rüya âlemi, tam anlamıyla, çürümüş bir şeyler dünyası olarak sunar kendini. Benjamin' in işi de on dokuzuncu yüzyıldan kalan, çoğunlukla gelip geçici olan bu şeyleri aramaktı. Meta fetişizmi ve yanlış bilincin fantezi dünyasına hapsolmuş olan, on dokuzuncu yüzyıldaki "rüya gören kolektif" tasavvuru, ayn ölçüde önemli bir kavramı, yani rüyadan uyanma kavramın gerektirir. Bu da arkasında yalnızca kökeninin izlerini bırakan fenomenal gerçeklik dünyasının yapısının bozulup yeniden yapılandırılmasıyla mümkündür (Frisby, 2012: 267).

Benjamin, kapitalizmin deneyimi ortadan kaldıran yapay dünyalarını titretmek ve uykusundan uyandırmak istemişse de bu yapaylık O'nu da etkilemiştir. Bu etkilenme iki şekilde kendisini göstermektedir. Benjamin'in Gerçeküstücü Andre Breton'un "Nadja"12 ve Louis Aragon' un "Paris Köylüsü" eserlerine olan derin ilgisi ve Benjamin'in Paris'e olan ilgisi. Paris Benjamin'in zamanındaki ile arşivlerde fotoğraflar ve belgelere dönüşmüş Paris'in büyüleyici kalıntılarıdır. İki Paris. Pasajlar, geçmiş ile şimdi arasında gidip gelen, belleğin salınımlarıyla gerçekleşen bir tarih araştırmasıdır. "Pasajlar" da "şiirsel ürün ve maddi varoluş, 19. Yüzyıl Paris'i ve 1930'ların Avrupa'sı karşılıklı olarak birbirine nüfuz" etmektedir (Lunn, akt. Özbek, 2000: 105).

Modernliğin şok yaşantısı, her şeyin yerli yerinden edilmesi, yabancılaştırılması, anlamlarını yitirmesi ve yeni anlamların kazanılmasıdır (Witte, 2002: 155). Paris, gittikçe artan nüfus için yeniden yapılanmak zorundaydı. Bu ise basit bir huzur mimarisi veya kent yapılanması anlamına gelmemektedir. Sermayenin dolaşımda olması, metaların görünürde kalması, onları üretenler kadar tüketicilerin onlarla buluşmalarının ayarlanması için tüm bir

10 Marks, bu sözcüğü kullanırken metaların fetiş görünüşünü sağlayan aldatıcı görünüşleri kapsamaktadır. Benjamin buna ek olarak metanın sergileme değerinin aldatıcılığından söz eder. Daha geniş ölçekte fantazmagoryalar tüm bir deneyime sinen aldatıcılık anlamına kavuşur (Buck-Morss, 2015: 100).

${ }^{11}$ Weber, modernizmin büyü bozumu olduğunu yazar. Büyü bozumu her türlü teknikleşmenin apaçı hale getirdiği bir doğa ve kültüre karşılıktır. Bu tema Marks ve Engels'in manifestoda tekrarladıkları bir temadir.

12 Benjamin bu romanın Paris üzerine olduğunu söyler (Buck-Moss, 2015: 50). 
kent seferber edilmeliydi. Vitrinler, fuarlar, pasajlar, dükkânlar ve modern tipler. Gece aydınlanan şehirde, zaman ve mekân deneyimi dönüşürken yeni bir tat alma ve ifade olanağ1 kendisini göstermekteydi (Buck-Morss, 2015: 107-109).

Simmel'in sonraları yazacağı üzere para ekonomisi ve elektriğin sürekli uyarıcı olduğu bir deneyim alanı sürekli sinirlerin uyarıldı̆̆ı bir ortam metropolün özelliğidir (Simmel, 2003). İletişim para üzerinden anlamını bulmakta, kişiler bu ilişkiler üzerinden sıfatlarını kazanmaktaydılar. Borçlu, alacaklı, satıcı, alıcı, işveren vs... (Benjamin, 2001: 133). Nasıl ki meta üretildiği an kente akın etmekte, insanların gözünde parıltısılla fuarlarda ve vitrinlerde kendisini sergilemekteyse, kalabalıklar da yabancıyı -onun kim olduğunu bilerek ve büyük bir sevinçle 'hoş geldin' diyerek değil- içine alarak bir yı̆̆ın olarak hayatlarına devam etmekteydiler. Modern karakterler, Benjamin'in "Pasajlar"ında boy gösterirler. Koleksiyoncu, fahişe, flaneur, dandy, bohem... Bunlar modern kültürün semptomatik okumalarının ürünü olan teorik figürler olduğu gibi yinelemek gerekirse tarihsel anlamda gerçek tiplerdiler. Uysal görünseler bile takıntılı ve özel tatlar uğruna aşırılıklara girişen modern Paris'in ürettiği deneyimler içinde yüzergezer tiplerdirler.

Flaneur, eşik karakterdir. On dokuzuncu yüzyıl Paris'indeki siyasi veya sınıfsal ilişkiler içinde bir sınır içerisinde gezindiğini görmek zordur. Sınırlar arasında görülebilinir ancak bir ayağı sınır dışındadır. O'nun bakış1 ${ }^{13}$ sürekli kılık değiştiren, bir gezginin kendisini satılığa çıkartacak kadar arsız, ancak bir yere ait olmayacak kadar uçuşkandır (Benjamin, 2001: 98,99). Kitle içinde bu gezgin veya aylak tip, estetik deneyimini kentin fantazmagoryalarıyla yaşamaktadır. "Olayları anında kapar; bu da, onun kendini neredeyse sanatçı sanmasına yol açar" (Benjamin, 2001: 135). Bir sanatçı, suç mahalline gelen bir dedektif, toplumun artığıyla oyalanan boş bir gezen. Kocaman açık bir göz: "Flaneur'de baskın öğe, bakınmanın verdiği zevktir. Bu bakınma, bir gözlem düzeyinde yoğunlaştığında, ortaya amatör dedektif çıkar; aynı bakınma bir şey anlamadan bakmayla sınırlı kaldığında Flaneur, bir badaud'a [alık alık gezen boş bakan] dönüşmüş olur" (Benjamin 2001: 163).

Metaların parıltısının tüm kente yayılmış atmosferinin gözü yoldan çıkartıcılığı bireyin hareketlerindeki kendiliğindenliğin azalmasına neden olur. Flaneur, bu yüzden bakma egzersizleriyle kendisini koruyabilmektedir ${ }^{14}$. Onun bakışı saf bir araştırmacı bakışı değildir. Dedektifliği kalabalıkların arasında iyi iz sürmesinden gelmektedir. İzin peşinde flaneur, modern rüya âleminden kaçınma pratikleri üretmiştir. Kent içindeki gezintisindeki nedensizlik, kendisini başka yerlerde bulması, gördüğü metada ya da doğa kesitinde, pasajların cam ve demir konstrüksiyon iskeletinde, moda bir giysinin kıvrımlarında

\footnotetext{
${ }^{13}$ Doğrusu buna alegorik bir deha olan Baudelaire'in kente dönük bakışı denilebilir. "Pasajlar" yarım kalmışsa da Baudelaire üzerine incelemeler olarak okunabilecek kadar şaire odaklanmış bitmiş yazılardan oluşmaktadır. Flaneur karakteri üzerine Benjamin Marks ve Poe gibi isimlerin tanımlamalarına da başvurur. Ancak bunlardan Baudelaire'in sözleri daha fazla göze gelmektedir.

14 Guy Debord ve Sitüasyonistler'in 1960'ların Fransa'sındaki düşünceleri flaneur'ün estetik devamlılığının siyasallaşmasına örnektir. Kentte gezinen aylaki durumları yaşayan ve onların anlık etkilerinde tazelenen bir hakikati deneyimleyendir. Debord'un fantazmagoryayı akla getiren gösteri kavramı her şeye bulaşmışlığıyla böylesi bir stratejiye neden olur. Bunun için bkz. Engin Ümer "Adorno, Debord ve Baudrillard'da Kültür ve Sanat" (2016: 171-187).
} 
fantazmagorik bir deneyim içerisinde yolculuk ederken düşlerden uyanmanın imkanlarını aramaktadır. Flaneur karakterinin aylaklığı ve kayıt altına alma isteği, bir dedektif gibi garip öngörüleriyle Marx'ın kendisini komplocu olarak tarif etmesiyle modern anlam dünyasının akışkanlığına kendisini kaptırmış bir kişilik, şimdi'nin tarihçisi ve estetidir. Flaneur'un değeri geçmişin yükünün hafiflemesinin, çocuksu uyarılmaların meydana getirdiği anlık amaçların, metanın auratik deneyimini biriktirmesiyle günümüz kimi tiplerin arkaik örneği olmasıdır.

\section{İcat Edilen Deneyim ya da Deneyimin Genişlemesi}

Sanatın mit üreticiliğgi, modernliğin yıkıcılığı içinde kökenlere dönüşün, yeniden tazelenmenin, unutulmuşa ağıtın kendisiyken artık mit üreticiliği kitlelerin aldatılışına karşılık gelmektedir. Sanatçı yüksek ideallerinin peşinde olsa bile artık bu rüya âleminin üreticisi konumuna gelmiştir. Sanat, gündelik modalara uygunlaştırılmış bir gösteri halinde insanlara sunulmaya başlanmıştır. Yazar, tefrika romanlarla gazeteden parasını kazanma derdine düşmüştür. Edebiyat gündelik haberlerin arasında kendisine yer bulurken formunu değiştirmiştir (Benjamin, 2001: 122). Fotoğrafın icadıyla portre ressamı gözden düşmeye başlamış, fotoğraf idealize edilmiş biçimi göze getirir olmuştur. Teknikleşmeyle her anlamda sanatın nedensiz ve kendiliğinden var olma hali hesaplanabilir olanla yer değiştirmeye başlamıştır. Hakikat, Balzac'ın "Mutlak Peşinde"sindeki simyacı karakterinin ölüm döşeğinde gazeteci çocuktan duyduğu şekliyle satılığa çıkmıştır bile (Balzac, 2015). Marx'ın paranın her şeye karşılık gelen gücünden bahsetmesindeki gibi on dokuzuncu yüzyılın perişan, fakir, gezgin ve bohem sanatçısının elini kolunu bağlamaktadır. Benjamin'in buna karşı konumu oldukça farklıdır. Lukacs gibi Marksistler sanat ürününü metanın karşısına koyarken, Benjamin "meta biçiminin kendisinden devrimci bir estetik" çıkartmaktadır (Eagleton, 2010: 399).

Sanat, Benjamin için kapitalist sistemin meydana getirdiği alanlaşmalar ve ayrımlaşmaların içinde varlık bulmaya çalışmakta, ona uyumlaşırken bunu görmemektedir. 1934 tarihli "Üretici Olarak Sanat" yazısı Benjamin'in sanat deneyimi ve estetik konusunda fikirlerini içermektedir. Politik bir sanatın didaktik ve dolayısıyla kendisini kaybetmiş şekilde araç görevi görmesinden rahatsızlık duyan Benjamin, üretici yazar tipinde deneyimi paylaşma imkânını görmektedir. Üretici olarak yazarın elindeki imkân, yazı araçlarını ve becerilerini sadece kendine ait görmeyip, diğerlerinin de bunlarla bir şeyler yapabileceğini biliyor olmasidir.

Diğer bir deyişle entelektüel üretim süreci, burjuva bakış açısına göre düzenini borçlu olduğu farklı uzmanlaşma alanları yıkılmadığı sürece, politik kullanıma açılamaz. Daha kesin bir ifadeyle, üretici güçleri ayırmak için yaratılmış olan uzmanlık engelleri, bu güçlerin ortak çabalarıla yerle bir edilmelidir. Üretici olarak yazar, proletarya ile dayanışmasında, o zamana kadar kendisi için pek bir şey ifade etmemiş olan belli diğer üreticilerle dolaysız ve kendiliğinden bir dayanışma yaşar (Benjamin, 2011: 81).

Benjamin, zamanının sanatlarının edebiyatın, müziğin ve tiyatronun kitle iletişim aygıtları karşısında kendi kabuğuna çekilerek, sanatçının üretim aygıtlarının kendisine ait olduğuna inanarak davranmasını eleştirmektedir. Benjamin için sanatın devamlılığı 
sanatçının diğeriyle yardımlaşmasıyla mümkündür. Sanatçı elindeki araçların sahibi olarak, onları kendisine saklayamaz. Kendi başına bunu gerçekleştiremez de. Bu nedenle belli bir izleyici kitlenin, bir sınıfın sanatını icra ederek, kapalı bir alan içinde sanat araçlarını muhafaza ettiğini düşünecektir. Burada ise sanat üretimi yanılsamaya kendisini kaptırır. Özerk alan kendisini kitle iletişim aygıtlarından, film ve radyonun gücünden uzak şekilde bulurken donuklaşmış ölü bir dili tekrar etmekten başka bir şey yapmayacaktır (Benjamin, 2011: 84, 85).

Brecht' in epik tiyatrosu ise bir öneri olarak karşımıza çıkartılmaktadır. Bu öneri radyo ve film aygıtlarının tekniklerini kullanabilen, onlarla diyaloga girebilen bir tavrı göstermesiyle şekillenmektedir. Epik tiyatro bu araçların üretim tarzı olan montaj ilkesini kullanmayı, durumlar meydana getirerek eylemi sekteye uğratmayı becerebilmiştir. Böylelikle eser, donuklaşmış bir kendilik bilinci yerine akışkan halde, şimdi içerisinde üretilmekte, kendi alanında donuklaşmış bir estetik deneyim yerine, izleyicisi için şaşırtıcı yabancılaştırıcı ve demistifike edici bir deneyim yaşatmaktadır.

Brecht'in tiyatrosunun epik olarak tanımlanmasını sağlayan (bu) kesintiye uğratma tekniği, sürekli olarak, seyircide yanılsama yaratmaya karşı çıkar. Böyle bir yanılsama, gerçekliğin öğelerini, bir deney düzeneğinin öğeleriymişçesine ele almayı planlayan bir tiyatronun işine yaramaz. Durumlar ise deneyim başlangıcında değil, sonunda yer alırlar. Bu durumlar şöyle ya da bu biçimde, kendi durumlarımızdır; ancak seyircinin yakınına getirilmemiş aksine ondan uzaklaştırılmışlardır (Benjamin, 2011: 86).

Üretici olarak yazar ya da sanatçı proletaryaya yakın şekilde, meydana getirdiği sahnelemede onun olması gerektiği bilinci ya da onun eleştirel imkânlarına eklemeler veya onun bu dilini besleyecek perspektifler üretmektedir. Ancak Benjamin burada onun bulunduğu yerin proletaryanın içinde olamayacağını söylemeden de geçemez (Benjamin, 2011: 89). Üretici olarak yazar, burjuva kültürüne aittir. Çünkü üretim aracı olarak eğitim imkânı böyle bir sınıfın elinde olduğu gibi onun imkânları bu eğitimi elde edebilmektedir de. Ancak üretici yazar böyle bir sınıfın içinden çıkacak ve yönelimini proletaryaya doğru hale getirecektir.

Makale sanatın deneyim imkânı olarak düşünülmesi konusunda şunları söylemektedir. (1) Sanat araçları zamanının teknolojik gelişmelerinden bağımsız kalamazlar. Bu olsa olsa eldeki ürünün değerini azaltmama isteği adına muhafazakâr bir tutum anlamına gelmektedir. (2) Modern sanat sistemi için özel bir figür olarak sanatçının beceri ve hünerleri ne kadar kendisine özel olsa bile herkesin sanatçı olabileceği, bunun özel bir deneyim olarak yaşantıya başka bir bakışla yönelmenin imkanları olduğu (3) kitlenin, ki burada proletaryanın burjuva bakış açısıyla kitle olarak görülebileceği, sanat yoluyla yabancılaştırıcı bir deneyim yaşayarak rüya âleminden kurtulabileceği (4) sanat araçlarının kitle araçlarıyla olan diyaloğundan onların meydana getirdiği auratik sahnelerin tersine bunları bozacak bir imkanın ortaya çıkabileceği. Bu görüşler ve özellikle sonuncusu Benjamin'in fotoğraf ve film aygıtı üzerine düşüncelerinde devamlılık göstermektedir. 


\section{Fotoğraf Deneyimi}

Gerçekliğin aktüel anlamda olay halinin yabancılaştırılması modern medya tarihinin ilk zamanlarından bu yana görülmektedir. Günümüz medya eleştirilerinin ana damarı olmayı sürdüren bu eleştiri basitçe iki şey söylemektedir. (1) Propaganda aracı olarak medyaların gerçekliği belli bir ideolojik perspektifle göstermesi, (2) aygıtın yabancılaştırıcı gücünün gerçekliğin etkilerini dönüştürmesi. İlk düşünme bilinçli bir yönelim olarak medyanın gerçekliği belli açılardan anlattığını önermektedir. İdeolojinin, bilinçdışı işleyişi gibi, gerçekliği ifadeye dökerken belli bir temsili önceden şart koyduğunu da söylemektedir. Buna göre iktidarın görünür olmasına gerek yoktur. O'nun cisimleşmesinden evvel bir bilinç düzeyi olarak o zaten her yerdedir. Bu Adorno'nun kültür yönetimi ile Foucault'nun söylem düşüncesi arasında gidip gelen bir düşüncedir. İkincisi düşünme ise aktüel gerçeklik ile gerçeklik arasındaki ilişkinin kaçınılmaz olarak soyutlama ve dolayım içerdiğini söylemektedir. Buna göre aygıtın dönüştürücü etkileriyle aktüel olanın içinde olma isteği mesafesizlik düşüncesinin ya da hissiyatının aygıtın mesafelendirici etkisiyle dağılmaktadır. $\mathrm{Bu}$ mesafe sadece olayın maddi gücünün etkilerinden uzak kalmak değil, olayın değerlendirmesinde mesafenin yabancılaştırıcı bir gücünün de olması demektir. Duyarsızlık ya da 'umarsızlık duyarlılık'15 medyanın yaydığı bir duygu durumu olmasıyla bu yabancılığa örnektir. Medyalar sürekli uyarımlarla ilgi çekici ancak duygu durumu olarak değişken ve yorgunluk hissiyatını hissettirmeyen bir durumu üretmektedir. Yine de ikinci durum aygıtın yabancılaştırıcı etkisinin potansiyellerini de akla getirmektedir. Benjamin bunu gündemdeki aygıtların imkânlarını kullanması ile epik tiyatro düşüncesinde açıklamıştır.

Fotoğrafın da böyle bir gücü vardır. Benjamin, her zamanki gibi modern kültüre özgü bir üretim tarzının tersten okunmasını, ondaki üretici ve dönüştürücü gücü fotoğraf üzerinden de önerir:

(...) önceleri kitle tüketiminden kurtulmuş olan bahar, ünlü kişiler, yabancı ülkeler gibi şeyleri modaya uygun biçimde işleyerek kitlelere sunmak, fotoğrafin ekonomik bir işleviyse; var olan şekliyle dünyayı, içinden -yani modaya uygun şekilde rötuşlayarak- yenilemek de politik işlevlerinden biridir (...) Fotoğrafçıdan talep etmemiz gereken şey, fotoğrafin altına, onu modaya uygunluğun getirdiği aşınmadan kurtaracak ve devrimci bir kullanım değeri kazandıracak bir başlık koyma becerisidir (Benjamin, 2011: 80).

Görsel imgeyle yazı arasındaki ilişki patlayıcı etkidedir. Basit bir söz, görüntüyü dönüştürücü bir güce sahiptir. Propaganda söyleminin tekniğindeki gibi. Bu tersine döndürme, medyanın faşist kullanımından çalmaktır. Benjamin'i fotoğrafın sanatsallı̆̆ kadar ilgilendirenin fotoğrafta sanatın ele geçiremediği bir şeylerin olmasıdır (Benjamin, 2012: 9). "Büyülü bir değer", "tesadüfün ufacık kıvılcımı" fotoğrafik imge ile izleyici arasındaki ilişkiye dair başka şeyler söylemektedir (Benjamin, 2012: 10). Fotoğrafik imgenin pozitivist karakteri açık ve seçik bir şahitliğin bilgisine karşılık bu bulanık bilgi, özel türden bir deneyimi önermektedir. Fotoğraf simya gücüne sahip şekilde, modelin imgesinin kendinde özel bir güç,

${ }^{15} \mathrm{Bu}$, Sabri B. Düvenci ile Samire Ruken Öztürk'ün "Postmodernizm ve Sinema" adlı kitaplarında Tarantino'nun filmlerini nitelemek için kullandıkları bir ifade. Günümüz medya etkileri içinde duyarlı görünürken eylemsiz kalmayı özetlemektedir (Düvenci ve Öztürk, 2014: 101). 
auratik bir deneyim meydana getirmesine yardımcı olan bir aygıt niteliği kazanmaktadır. "Fotoğraf karesinde, 'oradaki' bir insanın bilinçli biçimde ördüğü bir mekân yerine, bilinçsizce şekillenmiş bir mekan görünecektir. İnsanların nasıl yürüdüğünü -en kaba haliyle bileanlatmak kolayca mümkün iken, bir kişinin attı̆̆ı her adımda saniye saniye hangi pozisyonda olduğu konusunda kesin bir şey söylemek mümkün değildir" (Benjamin, 2012: 11).

Bellek metaforu olarak ${ }^{16}$ fotoğrafın onun rastlantısal veya bilinçsizce işlediğini göstermesiyle Benjamin, Proust'un bellek düşüncesini izlemektedir. Diğer taraftan dönemin avangard eğilimleri Benjamin'in fotoğraf düşüncesinin oluşmasında etkili olmuştur. Almanya'da varlık göstermiş olan modern sanat ekollerinden Bauhaus'un hocalarından Moholy-Nagy'nin yeni bir vizyon olarak gösterdiği fotoğraf ve kendisinin ürettiği çekim teknikleri bu etkilerden birisidir (Yacavone, 2015: 52). Nagy, fotoğrafik imgenin şimdi ve buradalığıyla oynayan deneyler yapmakta, fotoğrafın belgesel niteliğinin dışında kurgu niteliğini güçlendiren etkiler üretmekteydi. Fotoğrafik imgeye Nagy gibi isimlerin yaptığ bilinçli müdahalelerin meydana getirdiği bakış, fotoğrafik imgede görünürdür. Oynanmış imge, görünür hale gelmiş bir huzursuz etki, anlamı bilinmeyen bir duygu durumu meydana getirmek için seferber hale gelmiştir. Benjamin Dadaizm'in fotomontajlarında siyasi anlatının şoke ediciliği ve sıradan olanın otantikliğini ellemeden montajlarla bunların gerçekleştirilmesinden de etkilenmiştir (Benjamin, 2011: 80). Dadaizm'in sanatın kendi sınırlarını genişleterek başka bir estetik deneyimi amaçlamasına ilgi duymuştur. Aura deneyiminin estetik bir deneyim olarak düşünülmesi bunu göstermektedir. Burada estetik kelimesi duyumun bilgisi üzerine düşünmeye karşılık değildir. Aura deneyimi, belli belirsiz kendiliğinden varlık bulan, kişinin hissettiği ve aktaramadığı karaktere sahiptir. Bu modern estetiğin psikolojik boyutuyla buluştuğumuzu gösterirken, temsil edilemezin bir kategori olarak karşımıza çıkartılması olarak görülebilir. Bu açıdan aura deneyimi, bir yanıyla devrimci dönüştürücü gücü ve temsil edilemez mistik karakteriyle modern estetiğin örneklerinden görülebilir ${ }^{17}$.

Bu psikolojik boyut, derin bir hislenme, kişinin ruhsal süreçleriyle ilgili bir deneyimdir. Bu yorumlamaya imkân veren, Benjamin' in "optik bilinçdışı" ifadesidir.

(...) fotoğraf, zaman geçişleri ve mercek büyütmeleri gibi yollarla bu tür bir bilginin edinilmesini sağlayabilir. İnsan, nasıl psikanaliz vasıtasıyla bilinçdışının dürtüleri hakkında bilgi sahibi olabiliyorsa, bu yöntemler sayesinde de bu görsel bilinçdışı hakkında bilgi edinebilir. Yapı, hücre formalar, bu teknikler aracılı̆̆ıla tıbbın gelişmesi -fotoğraf makinesi son kertede bunlarla (...) daha yakından ilintilidir. Fakat aynı zamanda fotoğraf,

\footnotetext{
16 Bellek yazı ve sesten çok görüntünün alanı olarak görülmüştür. Bu yüzden de görsel aygitlar üzerinden metaforik şekillerde anlatıla gelmiştir. Bu konuda yetkin bir çalışma için Douwe Draaisma'nın "Bellek Metaforları" adlı çalışması önemli bir çalışmadır. Bu çalışma tarihsel düzen içinde görsel kültür ve görüntüleme aygitları ve teknolojinin değişimi üzerinden belleğin nasıl anlaşıldığını anlatmaktadır (Draaisma, 2014).

17 Temsil edilemez ve modern estetik konusunda "Tekinsizin Estetiği ve Sanat Yapıtı" adlı çalışmaya bakılabilir. Çalışma Kantçı yüce kategorisinin temsil edilemez olan ilgisi ve deneyimdeki öznenin sarsılmasını anlatmasıyla Benjamin'in bu düşüncesini anımsatmaktadır. Bu anımsatma modern estetiğin üst başlığı altında düşünülmelidir. (Ümer, 2017: 96-126).
} 
bu malzemeyle beraber görüntüler âleminin dişa vuran -berrak ama yine de hayallere sığınacak denli saklı- ufak detaylarının belirdiği yansımalan gözler önüne serecektir (Benjamin, 2012: 12).

Hikâye anlatıcısı, bir bellek ve ortaklık gerektirmekteydi (Özbek, 2000: 116). Fotoğraf ise bilinçdışı bir etkinlik olarak belleğin işleyişinin halk öyküleri ve destanların aktarımından farklı şekilde anlaşılmasını önermektedir. Destanlar ortak belleğe sahip bir iletişimin, toplumsal bağlayıcılığın olduğu zamanlarda değerler açısından deneyimin aktarımını anlamlı kılmaktadır. Fotoğrafik imge ise bilinçdışına kendiliğinden ve belli bir değer sisteminden bağımsız şekilde tetikleyici görevi görmektedirler. Benjamin'in ilgisini çeken avangard anlatım tarzlarından başka belgesel fotoğraflar ki bunlar istemsiz bir bakışı harekete geçiren özellikleri olmalarıyla deneysel fotoğrafların sahnelemesine göre farklı bir temsil pratiğine sahiptirler.

Fotoğrafçı Eugene Atget, Benjamin'in flaneur karakterinin bir örneğidir. Aynı zamanda aylakça gezintisinin anlık kayıtlarını biriktirmesiyle, bir koleksiyoncu figürüdür. Koleksiyoncunun nesnelerinin kendi başlarına bir tarihi, zamanın üstlerinde biriktirdikleri izleri ve diğer nesnelerle olan anlamsal ve ekonomik değerinin meydana getirdiği cazibesine karşılık Atget' in fotoğraflarında biriken imgeler, metropollerin şimdisi içinde gelip geçiciliği sabitlemektedir. Atget, insansız, sanki bir suç mahalliymiş gibi görünen fotoğraflarıyla modern zamanın şimdisinde saklı bir büyüselliği yakalama derdindedir. Bunu bilinçli olarak düşündürtenin (dört bini aşkın olan) Atget'in fotoğraflarının Benjamin'in sevdiği deyişle bu takımyıldızının kişide uyandırdığı anlamdan kaynaklanmaktadır.

Aura' dan arındırma Atget'in fotoğraflarındaki gizil güçtür (Benjamin, 2012: 24). Ancak sahneleri yeniden büyülenmenin gizemli çekiciliğine de sahiptir. Atget sıradan, detaylarda saklı, görünürde ahlakdışı veya bakılmasına pek de istekli olunmayacak olanların peşinde kenti dolanır ve anları yakalamaktadırlar. Eşyanın, boş mekânın, taşın, vitrin mankenlerinin, amblemlerin her türlü nesnenin sahnelemesini fotoğraflar. Yabancılaşmış bir duygu durumunu meydana getiren Atget'in fotoğrafları, modern mekânın sembolik dönüştürülmesini göstermektedirler. August Sandler'in her türlü sinıftan insanın portrelerindeki gibi. Atget'in tersine, Sandler yüze odaklandığı fotoğrafları bilimsel araştırma içinmiş gibi görünse de insanların deneyimlerini gösterme amacıyla aygıtın dönüştürücü gücünü kullanmıştır (Benjamin, 2012: 28).

Benjamin, fotoğrafın yabancılaştırıcı etkisini pozitif içeriğiyle erkenden fark eden ve bunu kuramsal düzeyde açıklama gayreti gösteren isimlerdendir. Aygitın dönüştürücü gücünü, üretim aygıtlarının emeği yabancılaştırmasında olduğu gibi olumlu yönleriyle ele almaktadır. Modern imge dilinin yönelimde olduğu kültürel eleştiride varlığının meydana getirilmiş bir imge dilinin işleyişini kendi işleyiş şekliyle değiştirmek olduğu görülmektedir. Bu modern görsel kültürün karakteri olarak günümüzde de anlamlı görülecek bir tavırdır. Tek farkla, Benjamin deneyimin yenilenmesini meydana getirecek bir sarsılmayı önermekteydi.

Teknik gelişmelerin eseri kopyalaması, onun sahiciliğinin değişimine neden olmuştur. İşitsel veya görsel kopyalar orijinallerin yerinden edilmiş şekilde başka bir hale gelmesine 
neden olurken söz konusu sahicilikten bahsetmek de gittikçe zorlaşmaktadır. Bir eser müzede veya bir sunakta olsa bile artık fotoğrafik imgesiyle bir kitapta, kişisel bir albümde veya kartpostaldadır (Benjamin, 2011: 95). Kültsel değerin daha önceleri yerini alan seyirsel değere karşılık modern teknolojiler kopyalara enformatik olma vasfı yüklemişlerdir ${ }^{18}$. Eser ise fetişleşmiştir.

Günümüz sanat piyasasında eserin biricik niteliği meta değeriyle iç içe geçerek, eserin özel seyrine içkinleşmiştir. Benjamin'in ilgilendiği böylesi bir değer kaybı değildir. O zaten kopyanın kaçınılmaz olarak orijinalin statüsünü sarsamayacağı bir zamanın içinden gelmektedir. Ancak Benjamin, sadece esere dair alımlamanın ve deneyimin değil, doğanın, insan varoluşunu kendi şimdi ve buradalığının kaybını da bize anlatmasıyla eserlerindeki deneyim kaybı ve yerini alan enformasyonun ya da fantazmagoryaların olduğu bir kültürde olunduğunu söylemektedir. Film makinesinin kopyaladığı manzara imgesi de şimdi ve buradalığını kaybetmektedir. Ancak imge tersine etkiler üretilerek kitlesel bir etkilemeye neden olabilmektedir. Basit bir algı düzensizliği fotoğraftaki amaçlanmayan duygusal etkiyi meydana getirebilmektedir. Bir tetikleyici ile izleyicinin merkezi konumu bakışının kendisine geri dönmesiyle bozulabilmektedir ${ }^{19}$. Böylelikle fotoğrafın teknik gücü görüntülediği eserin nadideliğini ve biricikliğini dönüştürürken onu kolektif bir imge haline getirmektedir (Benjamin, 2012: 32).

\section{Film Deneyimi}

“Berlin'deki Çocukluk Yıllarında"ki bir anısında Benjamin, kayzerpanorama deneyiminden bahseder. Görüntünün ağır aksak hareketlendiği bir zamanda, görüntülerin yersizyurtsuz hale geldiği, görüntüleme aygıtlarının yabancılaştırıcı gücünün başka bir deneyim imkânına neden olacağı bir dönemde küçük yaşlardaki Benjamin gelecekteki düşünme ve deneyimleme tarzının ilk görünümlerini bulur. Kayzerpanaroma'daki deneyim, görüntünün yanına müziğin işin içine girmediği bir zamanda "hayalgücünün beslenebileceği bir şey" ve insanı farklı yolculuklara götüren güçtedir (Benjamin, 2004: 16). Fragman halinde görüntülerin her birisinin arasında görüntülerin hareketi ve duyulan çıngırak sesiyle tek tek gözün önünden geçmesi Benjamin'in melankolik ve hüzünlü duygulanımını tetikleyen efektlerdir (Benjamin, 2004: 16).

(...) son izleyicileri çocuklar olan o sihir [kayzerpanaromanın] hiç zayıflamamıştı. Bu sihir beni bir öğle sonrası Aix şehrinin şeffaf resmi karşısında, çınar yaprakları arasından Cours Mirebeau'ya dökülen zeytuni ışık içinde, tabii benim hayatımın diğer dönemleriyle hiçbir ortak noktası olmayan bir zamanda, bir kere oynamış olduğuma ikna etmeye yeltenmişti. Zaten, yolculuklarda garip olan şuydu: Vardıklar uzak dünya her seferinde yabancı bir

\footnotetext{
18 Zamanın içinde nesnenin yüzeyinde birikenlerin içerdiği sahicilik, maddi olduğu kadar aslında deneyimin sahiciliğini sağlayan gözlemcinin bakışının zedelenmesi olduğu gibi aslında kopyalamayla "sarsilan nesnenin otoritesidir" (Benjamin, 2011: 96).

${ }^{19} \mathrm{Bu}$ konuda son kitabı "Camera Lucida"da Roland Barthes, punctum düşüncesiyle Benjamin'i anar gibidir. Barthes'ın punctum'u da imgedeki belirsiz düzeni, izleyicinin kendisinde meydana gelen bir hissiyat içinde anlaşılmalıdır. Bakışın imgede kaybolması ve geri dönerek bellekte bir dizi imgeyi canlandirmasıdır (Barthes, 2011).
} 
dünya ve bu dünyanın içimde uyandırdığı hasret her seferinde insanı bilinmeze ayartan hasret değil, zaman zaman daha hafif bir hasret olarak sila hasreti oluyordu daha çok. Ama bu belki de, her şeyin üzerine yumuşak yumuşak düşen havagazı ışı̆̆ııın eseriydi (...) Ola ki birdenbire ışık düzeninde bir hata, içinde rengin manzaradan kaybolduğu o nadir alacakaranlı̆̆ı yaratsın. O zaman, külden bir gök altında sükût içinde uzanıyormuş gibi olurdu görüntü; sanki daha demin, biraz daha dikkat etmiş olsam, rüzgârn ve çanlarn sesini duymuş olabileceğim hissine kapılırdım (Benjamin, 2004: 18,19).

$\mathrm{Bu}$ uzun pasaj ilk olarak aygıtın imgelerin meydana getirdiği etkiye karışarak yabancılaştırıcı olduğunu söylemektedir. Kayzerpanaroma, görüntülerin birbirinden farklı ya da benzerlikler kurulabilecek bir bağlam içinde her bir sahneyi izleyicisinin baktığı perdeden geçirirken çağrışımsal bir anlamlandırma meydana getirmektedir. Benjamin'in hafızasında kalan bunu kayzerpanaroma'nın düzeneğindeki çıngırak sesi ve fotoğrafları aydınlatan havagazıdır. Bunlar Benjamin'in büyüleyici bulduğu bir anın hatırlanmasının taşıyıcıları olarak anlamlıdırlar. İkinci olarak bu anının Benjamin'in modern fantasmagoryalara olan ilgisinin hissiyatını göstermektedir. 1900'lerin başında modası geçmeye yüz tutmuş, çocukların ilgisine sahip kayzerpanaroma, on dokuzuncu yüzyıl Paris'inin rengârenk dünyasının izlerini taşımaktadır. Son olarak da bu pasaj Benjamin'in yazı deneyiminin karakterini göstermesiyle ilgiye değerdir. Bulunan her bir fragmanı diğerleriyle birleştirerek bir bütünlük yakalamanın sadece göstermelik olduğu, her birine karşı duyulan heyecanın asıl olduğunu söylemektedir ${ }^{20}$. Tek başına bir deneyimin, fotoğraf ve resim imgeleriyle yapilan yolculukların bitmeyen sıla hasreti ile bitimsiz deneyimler ve anlam kırıntıları olması Benjamin'in yazılarında karşımıza çıkmaktadır. O sadece büyülenmiş dünyanın büyüsünü bozup devrimci hale getirmeyi amaçlamışsa da özlediği geçmişi anmaktan da kendisini alamamıştır.

Benjamin "Teknik Olarak Kopyalanabildiği Çağda Sanat Yapıtı" adlı yazısında sanatta bilinen kategorileri terk ederek yenilerinin gerekli olduğunu düşünür. Buna duyulan ihtiyaç ise, proleteryanın ve sınıfsız toplumdaki sanat teorilerinin azlığından kaynaklanmaktadır (Benjamin, 2011: 92). Böyle bir sanat ise kitle iletişim araçlarından hareketle düşünülebilir. "Üretici Olarak Yazar"da Benjamin'in düşüncesi, sanatın kitle iletişim aygıtları ve kültüründen uzak kalmaması gerekliliği ana unsurdur. Bu sefer epik tiyatro değil, Dadaizm bu konuda örnek olarak verilmektedir. Dadaizm, resim ya da edebiyatın bilinen yöntemlerini izlemektense sinemayla ilgili kategorileri kullanmış, yapıtı sinemaya benzer hale, "dokunsal bir niteliğe" büründürmüşlerdir (Benjamin, 2011: 116,117).

Benjamin, sinema deneyimini resim deneyimi ile karşılaştırarak onda düşünmenin gücünün azaldığını düşünmüştür. Etkileyici bir tespitte bulunarak resim sanatının on dokuzuncu yüzyılda kitlenin kendisine bakmasıyla sonunun geldiğini, resmin kitle sanatı olamayacağını, resmin bakan kişinin onun içine daldığı bir deneyim sunduğunu sinemanın ise akan giden görüntünün karşısında izleyicinin sürekli şoke olmasına neden olduğunu yazar

20 "Pasajlar" Benjamin için montajlanmış ve yazarın sözünün aza indirgendiği fragman bir metin olarak düşünülmüştür. Bugün yaygın olarak bitmiş ve özellikle Baudelaire'e odaklanmış bir yazı dizisi sadece belli başlı nedenlerle bitirilmesi gereken yayınlardır. 
(Benjamin, 2011: 117). Sinema seyrini, imgelerin meydana getirdiği rüya âleminin şok etkisini olumlu bir güç olarak görür. "Fotoğrafın Kısa Tarihi" metinindeki 'optik bilinçdışı' kavramı, sinema ile anlam kazanır ve kamera ile "optik bilinçdışından" "haberdar oluruz" diye yazar (Benjamin, 2011: 115). Sinema bir ilaçtır. Merceğin hareketi, detaylandırmalar, çekim tarzları kameranın tüm imkânları ve montaj teknikleri onun büyüleyici özellikleri yeni deneyim imkânları sunmaktadır.

[sinema] tahmin edemediğimiz bir hareket alanı sağlamayı da başarır! Meyhanelerimiz ve büyük şehirlerin caddeleri, bürolarmız ve mobilyah odalarımı, tren istasyonlarımı ve fabrikalarımız bizi umutsuzca kuşatmış görünüyordu. Sonra sinema çıka geldi ve bu zindanlar dünyasın saniyenin onda birlerinin dinamitleriyle paramparça etti; öyle ki şimdi biz onların dört bir yana dă̆̆lmış enkazı arasında kayıtsızca, macera dolu yolculuklar yapıyoruz (...) Böylece kameraya hitap eden doğanın, göze hitap edenden farklı olduğu açıklık kazanıyor. Bu farklılık özellikle insanların bilinçli olarak oluşturdukları bir uzamın yerini, bilincine varmadan oluşturulan bir mekânın almasından kaynaklanıyor (Benjamin, 2011: 115).

Teorik ve tarihsel açıdan daha ilk evrelerinde olan sinema, onunla karşılaşan izleyicisi olmayı yeni yeni öğrenebilmiş kitleler için oldukça yeni bir deneyim sunmaktadır. Modern kültürün gelip geçiciliği, sürekli yenilik yanılsamasının, metalarla örülü büyüleyici bir ağın fantazmagoryalarının ya da 1930'ların teknolojik hızına ayak uydurabilecek bir bilinçte belleğin yerini alan salt imgenin geçip durduğu bir deneyim. Bellek yitimine, hikâye anlatıcısı veya çocuk olmanın kendisine duyulan derin ilgiyi örten yeni bir deneyim tarzı. Hikâye anlatıcısının ortak bellek gereksinimi, kıssadan hisse misali kuşaklarca aktarılan deneyimin yerini gündelik sıradanlığının büyüleyici imgeleri alır. Optik bilinçdışı, burada ortaklığa işaret eder. Çocukluğun saf ve bütünleşik dünya tasarımındaki rengârenk algı dünyası sinema deneyiminin imgeler geçidine yerini bırakır.

Sinema aygıtının dolayımıyla dünyaya bakmak, gözün yerini alan bir aparatın, perdede hareket eden kameranın iletişimiyle dünyaya bakmaktır. Gözün kör edilişi, bilinçli bir istek ile kendisini göstermektedir. Sinema büyülenmiş modern kültürde kentin ortasında dolanırken tasnifler, düzenler ve sıraya dizer. Bu yüzden sinematografiyi akışkan modern kültürün dondurulması olarak görmek, koleksiyoncunun biriktirme isteğinin istemsiz şekilde bilinçdışı imgeleriyle mümkün kazanması şeklinde düşünmek demektir.

Sinema aygıtı karşısında insan varlığı aura'sını yitirir. "Şimdi insanın aynadaki görüntüsü, ondan koparılabilir, taşınabilir olmuştur" (Benjamin, 2011: 107). Resim sanatında imgenin modeliyle olan ilişkisi modelinin şimdiliği ve buradalığını kesinleştirmesine göre sinemayı geçişken ve büyü bozucu olarak görmemize neden olur. Resim imgesi modelini anımsatır. Resim imgesi zaten modelinin yerine geçmiştir. Yerine geçme, bir saygı içermeden olmaz. Resim imgesinin modelinin yerine geçmesindeki güçlendirici boyut, onun varoluşunu kendi bünyesinde yeniden üreterek bir başka zaman ve mekân içine sokmasıdır. Bu hem resmin kendisinin içselliğinde hem de bir nesne olarak resmin kendisinde mümkündür. Sinema ise böyle bir saygı derdinde değildir. Sinema aygıtı yabancılaştırmayı, illüzyonu etkin şekilde vermesiyle, modeli bölmesi ve düzenlemesiyle gerçekleştirir. Aygıtın çektikleri bu 
yüzden aurasını yitirmek zorunda kalır. İzleyici kendi şimdi ve buradalığını yitirmiştir ve sinema perdesine bakarken rüyamsı bir âleme giriş için sabırsızdır. Bu âlemde deneyimleme seyrin sürekli akan imgeleriyle gerçekleşmektedir.

Montaj, kurgu ve kadraj düzenleyeceği kompozisyonlarla deneyimleri çeşitlendirici kapılar açar. Yinelemek gerekir ki Benjamin teknolojinin etkilerini derin etkilere neden olur şekilde anlamayı önemsemektedir. Nasıl ki akan imgelerin sürekli zihni diri tutan hareketliliği imgenin meta parıltısını güçlendirme etkisi var ise yavaşlatılmış bir sahnenin izleyicinin gözünün bu parıltıyla kamaşmasını azaltmak etkisinden bahsedebiliriz. Bellek, kişiselliğiyle devreye girebilir. Anımsama, sahnedeki bir jest, bir mimik veya bir mizansenin kendisi bellek deneyimini devreye sokabilir. Tanıdık hikâyeler, yaşamın tanınır olabileceğini hatırlatabilir.

Yine de bunlar sinemanın potansiyelleri arasında görülerek geçiştirilmelidir. Benjamin "Teknik Olarak Kopyalanabildiği Çağda Sanat Yapıtı"nı yazdığı dönemde sinema aygıtı hala hayranlık uyandırmaktaydı. Teoriler yavaş yavaş gelişirken, endüstri kuruluşunu hızla sürdürüyor, deneysellik, bu aygıtla nelerin yapılabileceği üzerine düşünmeler ve uygulamalar sürüyordu. Günümüzdeki iletişim ağı olmadığı gibi, aygıtın çok yönlü kullanımı kadar bunun meydana getirdiği bir birikimden söz etmek de oldukça zordur. Diğer yandan Benjamin, bu makaleyi kitle iletişim aygıtlarını oldukça etkili şekilde kullanan faşizmin gölgesinde yazmıştır. Bu yüzden O'nda sinema aygıtının gerçekliği ele geçirme isteğine uygun olduğu gibi bir yorumla ve de kitlenin sanatla ilişkisi üzerine bir yorumla da karşılaşmaktayız.

Benjamin, kitlenin sinema deneyimiyle ilerici bir durum ile karşı karşıya olunduğunu yazar (Benjamin, 2011: 112). Bu oldukça ilginçtir. Chaplin filmlerine karşı hoşgörü ve estetik ilgi içindeki kitlenin Picasso'nun resimlerine olan kaba yorumlamasının farkını anlamak zordur. Benjamin'in buna yorumu deneyimin kişiselliği ile kitleselliği arasındaki farktır. Sinema, tıpkı mimari gibi kitleseldir. Resim ise kişiseldir (Benjamin, 2011: 112,113). Deneyimin kitleselliği önceden belirlenmiştir. Sinema bunu ister, çünkü o kendinde kitle beklentisini üretmiştir. Sinema filmini tek başına izlemek ve tefekküre dalmak ne kadar mümkün olsa da kitlesellik içkin olarak onda varlığını sürdürmektedir. Sinema deneyimi, yanılsamanın kendisinden kaçamaz. Ancak yanılsama salt biçimsel tam uygunluk değildir. Bu izleyicinin kendi gerçekliğine dairdir. Sinemanın teamüllere uygunluğu Picasso'nun veya gerçeküstücü teamülleri görünür kılmayan veya onlarsız bir kişisel beğeni isteğindeymiş gibi duran tavrını izleyici için makul kılar. Sinema, izleyicinin temsillerine dokunma gücünü elinde tutar. Bu saf optik veya saf hareket anlaminda olsa bile.

Sinema ve fotoğraf, sanat deneyiminin dünyevileşmesinin, beğeninin kültürel derinliğinin bitişinde yeni bir deneyim evresinin işaretçileridir. Kült değerinden estetik değere geçiş, Rönesans ile başlayan estetizmin dünyevi hazlara, hakikatin işaretlerini dünyada bulmaya dönüşmesine, yüzlerce yıldır süren mimesis kategorisinin eserin belirleyici ilkesi olmasına modern kültür ile teknik aygıtların imge üretimini teknikleştirmesiyle dönüşüme gitmiştir. Sanatı zora sokan, bu aygıtların yanılsamayı ele geçirmeleri değil, artık yanılsamanın gücüyle anımsamayı kolaylaştırabilmeleridir. Resim imgesi saklar, imge modeline dair oluşunu birebir biçimsel tam uygunluğun gücüyle elde etmez. İmgenin bakışta beliren işaretlerindeki anlamlarda her bir çizginin hakikatin görünümü olmasında bunu 
gerçekleştirir. Fotoğrafik imge resmin sonunu getirmişse resmin bu saklama gücünün yitirilmesinde de anlam aranmalıdır.

Merceğin izleyicinin bakışının yerine geçmesiyle eserin kült değeri nihayete ererken estetik deneyimde başlamıştır. Sinema imgesi yeni bir kült değerine, Benjamin'in "Pasajlar" ile gerçekleştirmek istediği rüya bozumuna karşı olarak yeni rüyalar üretme gücüne sahip olmuştur.

Rüya gören kitlenin kendisini bulabilmesi adına sanat ideoloji perdesini yırtmalıdır. Estetik şeyleşmiş, eser teknik bir üretim halini almıştır. Benjamin'in önerisi ise kendi zamanı içinde Brecht'in epik tiyatrosunun ürettiği estetik deneyimin yabancılaştırıcı gücünün kitlelere buluşturulmasıdır. Eserin politik değeri, eserin belli ideolojilerce kullanımıdır. "Faşizmin siyaseti estetikleştirmesi böyledir" diye yazar Benjamin ve ekler "komünizmin buna yanıtı sanatı siyasileştirmektir" (Benjamin, 2011: 122).

\section{Bugün Benjamin}

Kimi düşünürler yaşamlarıyla düşünceleri arasındaki mesafesizlikle tanınırlar. Bu yüzden düşünceleri hakkında konuşmak onların hayatlarının izleri olmadan imkânsız görünür. Benjamin de bu düşünürlerdendir. Hiçbir yazı onun hakkında hiçbir konuşma yaşam öyküsünden bir an olmadan gerçekleşemeyecekmiş gibidir. Belki de Benjamin'in düşüncelerinin kendisi üzerinden gerçekleşmiş perspektifler sunması bunda etkilidir. Hikaye anlatıcısı da O'dur, çoğaltılabilir çağın imge seyrine kapılarak bilinçlenecek olan kitleler de O'dur. Koleksiyoncu da O'dur, çocuk da.

Benjamin işletilebilir bir teori ortaya koymamıştır. Düşünceleri üzerinden modern kültürün şafağından 1930'lu yılların Avrupa'sına kadar, içinde dolanmak zorunda kalırız. Bu hoş bir anlatının dinlenilmesi modernitenin arazlarını derinden hissetmenin evrensel öyküsünün dillendirilmesine şahit olunmasıdır. Bu yüzden Benjamin gerçek bir hikâye anlatıcısıdır. Çünkü O'nun yazıları sadece O'nun sözüyle sınırlı kalmaz. Benjamin hakkında yazılanlarda döneminin diğer entelektüellerinden, gelişmelerinden ve olaylarından kaçınılmaz olarak bahsedilir. Benjamin dinleyicisinden bir şeyler söylemesini yarım kalmış söze bir şeyler eklemesini istemesini ister.

Benjamin 'şimdi?' diye sormanın garipsenecek bir tarafı olmasa gerek. Buna cevaben ilk olarak O'nun kitle kültürü üzerine düşünmelerinden hareketle günümüz alternatif medyaları ve sanat ortamlarındaki kimi olgular hakkında derin öngörüler üretmiş olduğudur. Benjamin, ütopya ruhuyla anlamlı olduğu bir zamanda 'devrim' kelimesini kullanmıştı. İdeolojilerin sona erdiğinin müjdelendiği gösteri zamanımızda Benjamin'in görüşleri derin birer öngörü olarak ele alınabilir.

Günümüz ana akım medya, kitle kültürünü hala tipikleşmiş haliyle üretmekte ve tükettirmektedir. Kitleler, gruplar, kesimler, ideolojik topluluklar, ortak görüş sahipleri kendi medyalarını meydana getirerek, kendi mesajlarını ve mesaj üretme tarzlarını belirlemektedirler. Bilinçlen(dir)mek, didaktik olma pahasına bir görüş ortaklığı meydana getirme, Benjamin'in son dönem eserlerinde görülen bu gibi istekler günümüzde 
gerçekleşmiştir. Benjamin, teknolojiye içkin bir deneyimi düşünmüştür. O'nu gerçekçi kılan özelliği de budur. Teknolojik bir belirlenimciliği net bir şekilde savunmamış olsa da düşüncelerinde dinleyicisini ikna eden noktayı yakalamış gibidir.

Bugünün dijital kültürünü görmüş olsaydı acaba Benjamin ne derdi? Büyük bir ihtimal ile umut dolu bir bakışla imgenin üretimindeki enflasyonu görür, koleksiyoncu gibi onları koklardı. Onları deneyimlerdi. Sanal kültürün imgelerinin köksüz ve modelsizliği karşısında metalaşmış imgeler dünyasının kendine özgü takımyıldızları haline geldiğini düşünür ve psikolojik bir etkilenme ile büyüleyici bir anın tezahür edebileceğini dile getirirdi. Bugünün özelleştirilmiş deneyim mekânlarının büyüleyicilikleri 'Pasajlar' kadar O'nu heyecanlandırabilirdi. Günümüz görüntüleme teknolojilerinin canlı yayın uzaydan dünya görüntüleri gösteren Nasa'nın YouTube kanalını ilgiyle izlerdi. Bir bellek olarak internetin demokratikleştirici ve en önemlisi bireyi atomize eder görünen sınırsız özgürlükçülüğünü, montaj ve kolajın, kes yapıştır veya kaydet kültürünün içinde bitimsiz bir bilgi diyarında kendisine yeni koleksiyonlar yapar, yeni bilgilerin peşinde olurdu. Deneyimin günümüz kültüründe turistlik özel etkinlik halini aldığını düşünürsek, tinsel yenilenme için reklam görüntülerinde otantik hale getirilmiş ülkelere, bedensel keşifler için adrenalin sporlarının yapıldığı doğa harikalarına, kültürel turizm için dünya turuna çıkabilirdi. O'nu aylak aylak AVM'lerde ya da Disneyland' da gezerken bulabilir, bunlar hakkında ümit dolu fetişin içerdiği potansiyeller üzerine yazılar okuyabilirdik.

Böyle bir kurgulamada Benjamin'in entelektüel üslubunun ve düşüncelerinin başarısı kolaylıkla görülmektedir. O, Port Bou'da sadece yaşamına son vermiştir. Ancak arzuları gerçekleşmiştir. Bizler bugün aldatıldığımız kadar imgelerden kaçabildiğimiz kendi büyüleyici dünyalarımızı kurabildiğimiz, aplikasyonlar ve programlarla montajlamalar, fotoğraf işlemeleri yapabildiğimiz, kendi mesajlarımızı Dada fotomontajları gibi üretebildiğimiz bir sınırsız özgürlük zamanında yaşamaktayız. Avangard sanatın yazı ve görüntü konusunda harcama arzusu günümüz sosyal medyasında kabul görmüş bir dilin arkaik görünümü gibidir. Bizler bu dile o kadar alışkınız ki yabancılaştırıcı ve şoke edici etkileri bertaraf edebilmekteyiz. Medyaların olayları mesafelendirmesine alışkınız çünkü kandırıldığımızı biliyoruz. Mail gruplarından forumlara kadar ideolojik ortaklıklarımız olan arkadaş çevremizle bunu tartışabiliyor, fikirler üretebiliyoruz. İktidarla sosyal medya hesaplarımızdan dalga bile geçebiliyoruz. Dadacı nanik, günümüz için sıradan bir sosyal medya tepkisi halini almıştır.

Bugün Benjamin çağında yaşamaktayız. Sınırsız bir deneyim ortamında turist veya sanal âlem aylağı olarak yaşamakta, kendi görsel dilimizi, sosyal medya avatarlarımızdan sayfa düzenlerimize kadar gerçekleştirmekteyiz. Her birimiz koleksiyoncuyuz. Kendi ve başkalarının fotoğraflarını biriktirmekteyiz. Her birimiz aylak olarak boş zamanlarımızda sanat eserleriyle büyülenmekte kendi küçük alt kültürlerimizde ya da beğenisi gelişkin arkadaş ortamımızda tinsel derinlikli bir deneyim dünyasında yaşamaktayız. İmgeler bizler için özgürleştirici imkânlarını, ters yüz edilebilir olmalarını hala korumaktalar. Bu yüzden Benjamin'in katılaşmış modern kültürün içindeki devrimci uçuşkanlığını özgürlükçü bir öneriyle öne sürmesini kolaylıkla günümüzde motto bile ilan edebiliriz. 
Modern kültür başından bu yana çocuk üzerinden kendisini kurmuştur. Oldukça iddialı ve sıkıntılı görünecek bir ifade bu. Ancak modern kültürün gençlik kültü, ölümden kaçışı, tıbbi estetiğin ve sağlık sektörünün sloganı olan güzelliğin üretildiği bir kültürde bu garip değildir. Bugün, dün gibi modalar her kişiyi güzel kılmak için ideal tasarımlar meydana getirmektedir. Çocukluk, ideal erkek imgesi içinde sadece çekici bir erkeğin haşarı imgesinden başka bir şey değildir. Ya da kadın bir modelin çocuksu güzelliğinden bahsetmekten farklı değildir. Güzellik kültü kitle kültürünün gençlik arzulamasını ölüme karşı koyuşunun adıdır. İmgeler insanın arzulamasını harekete geçirir bir ideal imge olma gücüne sahiplerdir. Reklamlardan filmlere cinsel kimliklerin hala gösterdiği bu değil midir?

$\mathrm{Bu}$ oldukça tipik bir okuma, genel geçer bir medya analizidir. Ancak çocukluk üzerinden yükselen ve onu bitirmeye hevesli olan modern kültür, modern aile üzerinden steril bir çocukluğu karşımıza çıkartmaktadır. Günümüz ailelerinin ebeveyn dertleri çocukları için gelecek kaygıları, eğitim kalitesi, akranları arasında özel hissettirecek özek ilgilerin nasıl uyandırılacağı bunu göstermektedir. Steril çocukluğun anıları, böylesi bir kendilik teknolojileriyle önceden verili bir amaca göre şekillenmektedir.

Benjamin'in çocuk karakteri her şeyi kendi bakışlarıyla deneyimleyebilen düzenin yapısını titreştirebileceğini bilen bir güçtür. Çocuğun görmesi saf bir görme ile nesnesiyle bütünleşik, mitik zamanlara ait bir epistemoloji sunarken günümüzde çocukluk hem çocuklar için hem de yetişkinler için kaybedilmiş bir şey değil, unutulmuş bir şeydir. Burada kaybedilen deneyimin kendisi değil midir? Benjamin'in düşüncesinin olmazsa olmazı devrimin günümüzdeki kayıp hali çocukluğun kaybı ve deneyimin anlam eksikliği arasında bir ilişki söz konusu değil midir? ${ }^{21}$.

Benjamin'in haklı düşüncesi, bizleri saran bu imge dünyaları, şeyleşmenin ve yabancılaşmanın içerisinden çıkartılabilecek yeni imkânlar hala mümkündür. O'nu basit ama keskin görüsü, Lukacs ve Adorno gibi diğer Marksist ütopyacılığının bir yok yer üzerinden yükselmesine karşılık mümkün olan dünyanın içinde olduğumuz dünyadan yükseleceğini görebilmesinde saklıdır²2.

\footnotetext{
${ }^{21}$ Susan Buck-Morss bu konuda şunları yazmıştır: “Benjamin' in çocuğun bilincinde bulduğu ve burjuva eğitimle varlığı törpülenen ve (yeni bir biçim içinde olsa da) kurtarılması çok büyük önem taşıyan şey, yetişkinlerde devrimci bilinci ayırt eden algıyla eylem arasındaki kopmaz bağdı" (Buck-Morss, 2015: 290).

22 Benjamin'in Marksizmdeki konumu Sovyetlerdeki katılığı terk eden bir konum. Brecht ve Lukacs okumaları etrafında şekil kazandığı söylenebilecek bir konum. Batı Marksizmi içerisinde ise, Lukacs'tan farklı olarak Avangard yazına derin ilgi duyduğu gibi kendi yazın anlayışı bundan etkilenmiştir. Adorno ve sonraları Gramsci ve Althusser gibi isimlerin ideoloji perdesi düşüncesinin ürettiği yapay olan ile sahicilik arasındaki çatışkı Benjamin'de Nietzschevari bir yanılsamalar dünyasında saklı bir devrimci potansiyelle karşılanmaktadır. Benjamin'in Lefebre ve Debord gibi isimler ile aynı hatta yer aldığını söylemek daha mümkündür. Gündelik olanda saklı büyü düşüncesi, açıkçası devrimci potansiyeli gelecekte maddileşecek bir mekândan önce performatif gördüğü şeklinde bir iddia bile ortaya atılabilir. Benjamin'in konumu yöntem olarak arkeolog ve stil olarak avangard yazını izlemesiyle, bir öneriler silsilesi görülebilecek bir düşünme sunmamasıyla Marksist düşüncede oldukça farklı bir yere sahiptir.
} 
Benjamin, günümüzün sınırsız özgürlük yanılsamasında eksik olanın çocukluk olduğunu, bu ortak belleğin imkânsızlığını net bir şekilde görebilirdi. Zaten görmüştü de. Son dönem yazılarında imgenin kendiliğinden büyüleyiciliği ve harekete geçirici tasavvuru Benjamin'în bugünün emarelerini yaşadığını göstermektedir. Faşizmin köklendiği bir zamanda, fotoğrafik ve sinema imgelerinden anıların belirgin görüntüsünün değil de bilinçdışı titreşimlerinin parlattığı sahnelerin belirsizliğinde deneyimi önermesi belki de bu yüzdendir. Ancak günümüzde aranmakta olan bir şey daha var ise bu siyasalın ne olduğu ve olabileceğine dair imkânlardır.

\section{Sonuç}

Bizim 'şimdimiz' içinde Benjamin akademik bir figür olarak anlamlı görülmektedir. Bu da bir başka Benjamin yorumudur. Ancak O entelektüel olarak ne kadar anlamlıysa, harekete geçirici bir güç olarak o kadar düşündürücüdür. Bugünün sınırsız deneyim simülasyonlarının psikolojik varoluşumuzu sürekli harekete geçirerek bedensel bir uyarım yanılsaması meydana getirmesi, deneyimin içeriğinin çoktan boşaldığını, deneyimin, tüketim ile birlikte düşünülmesi gerektiğini bize söylemektedir. Bunu günümüzün kültürel ufkunun anahtar kelimelerinden birisi olarak görmek bile mümkündür: Tüketim (May, 2012: 97). Modern üretimciliğin ardından her şeyi tüketen, üretime içkin bir tüketim pedagojisinin ve estetiğinin olduğu bir zamanın bireyleri olarak yaşamaktayız. Devrimsiz, yani üretimsiz bir gelecek tasavvurunun günümüz kültürel ufku olduğunu söylemek postmodern şüphecilik, karamsarlık veya kinikliğin bir tezahürü sayılabilir23. Ana akım Hollywood sinemasının temalarından olan felaket filmleri bunu göstermiyor mu? Ya da distopya türünün geçen yarım yüzyıldır bitmeyen bir ilgi içermesi? Her biri belirti olarak anlamlıdır. Kendi ufkumuzun sürekli bir felaket ve yok oluşumuzu düşlediğimiz ile ilgili olduğunu söylemektedir. Belki de Klee'nin Angelus Novalus resmine bir kez daha bakmakta fayda vardır24.

${ }^{23}$ Bunun en bilinen örneği Fransız sosyolog Jean Baudrillard'dır. Baudrillard çarpıcı retoriği ve düşünme tarzıyla ileri kapitalist toplumların anlatısını yapar.

24Şöyle yazar Benjamin:

(..) meleğin görünüşü, sanki bakışlarını dikmiş olduğu bir şeyden uzaklaşmak ister gibidir. Gözleri, ağzı ve kanatları açılmıştır. Tarihin meleği de böyle gözükmelidir. Yüzünü geçmişe çevirmiştir. Bizim bir olaylar zinciri gördüğ̈̈müz noktada, o tek bir felaket görür, yıkıntılar birbiri üstüne yığıp, onun ayakları dibine firlatan bir felaket. Melek, büyük bir olasılıkla orada kalmak, ölüleri diriltmek, parçalanmış olanı yeniden bir araya getirmek ister. Ama cennetten esen bir firtına kanatlarına dolanmıştır ve bu firtına öylesine güçlüdür ki, melek artık kanatlar kapayamaz. Fırtına onu sürekli olarak sırtını dönmüş olduğu geleceğe doğru sürükler; önündeki yıkıntı yı̆̆ın ise göğe doğru yükselmektedir. Bizim ilerleme diye adlandırdığımız, işte bu firtınadır (Benjamin, 2001: 42). 


\section{Kaynakça}

Alpyağıl, Recep, (2007). Benjamin' in Mistisizmine "Üç Yönlü Yol". Cogito: Walter Benjamin Sayı: 52. İstanbul: Yapı Kredi Yayınları. s.201-210.

Armaner, Türker, (2007). Port-Bou'da Susan Dil: Walter Benjamin. Cogito: Walter Benjamin. Sayı: 52/Güz. İstanbul: Yapı Kredi Yayınları. s.138-148.

Balzac, Honore de, (2015). Mutlak Peşinde. İstanbul: İş Bankası Yayınları.

Barthes, Roland, (2011). Camera Lucida. İstanbul: 6:45 Yayınları.

Baudelaire, Charles, (2003). Modern Hayatın Ressamı. İstanbul: İletişim Yayınları.

Benjamin, Walter, (1998). Öykünme Yetisi Üzerine. Defter Dergisi, Yaz, Say1: 34, İstanbul: Metis Yayınları. 11-14.

Benjamin, Walter, (2001). Hikâye Anlatıcısı. Nurdan Gürbilek (der.), Son Bakışta Aşk, İstanbul: Metis Yayınları, s.77-101.

Benjamin, Walter, (2001). Tarih Kavramı Üzerine. Pasajlar. İstanbul: Yapı Kredi Yayınları. s.3750.

Benjamin, Walter, (2001). XIX. Yüzyıl'ın Başkenti Paris. Pasajlar. İstanbul: Yapı Kredi Yayınları. s.87-108

Benjamin, Walter, (2001). Charles Baudelaire: Kapitalizmin Yükseliş Çă̆ında Bir Lirik Şair. Pasajlar. İstanbul: Yapı Kredi Yayınları. s.108-202

Benjamin, Walter, (2001). Kendi Başına Dil ve İnsan Dili Üzerine. Nurdan Gürbilek(der.),Son Bakışta Aşk, İstanbul: Metis Yayınları, s.169-183.

Benjamin, Walter, (2004). Bin Dokuz Yüzlerin Başında Berlin'de Çocukluk. İstanbul: Yapı Kredi Yayınları.

Benjamin, Walter, (2005). Gelecekteki Felsefenin Programı Üzerine. Besim Dellaloğlu (der.). İstanbul: Say Yayınları. S.125-137.

Benjamin, Walter, (2005). Kütüphanemi Yerleştirirken. Besim Dellaloğlu (der.). İstanbul: Say Yayinları. s.151-159.

Benjamin, Walter, (2007). Zentralpark. Cogito: Walter Benjamin. Sayı: 52/Güz. İstanbul: Yap1 Kredi Yayınları. s.183-201.

Benjamin, Walter, (2011). Sürrealizm: Avrupalı Aydının Son Fotoğrafı. Ali Artun (editör).Sanat/Siyaset. İstanbul: İletişim Yayınları. S.51-69.

Benjamin, Walter, (2011). Üretici Olarak Yazar. Ali Artun (editör).Sanat/Siyaset. İstanbul: İletişim Yayınları. s. 69-91.

Benjamin, Walter, (2011). Teknik Olarak Kopyalanabildiği Çă̆da Sanat Yapıtı. Ali Artun (editör).Sanat/Siyaset. İstanbul: İletişim Yayınları. s.91-130. 
Benjamin, Walter, (2012). Fotoğrafin Kısa Tarihi. İstanbul: Agora Kitaplığ1.

Benjamin, Walter,(2016). Deneyim ve Yoksulluk. Parıltılar. İstanbul: Belge Yayınları. s.25-33

Benjamin, Walter, (2016). Hikâye Anlatmak ve İyileşmek. Parıltılar. İstanbul: Belge Yayınları. s.7374

Buck-Morss, Susan, (2015). Görmenin Diyalektiği Walter Benjamin ve Pasajlar Projesi. İstanbul: Metis Yayınları.

Çakmak, E. Efe (2005). "Kant: Filozof Kral". Cogito Kant Özel Sayısı. İstanbul: Yapı Kredi Yayınları. s. 8-31.

Dellaloğlu, Besim, (2012). Benjaminia. İstanbul: Ayrıntı Yayınları.

Draaisma, Douwe (2014). Bellek Metaforları. İstanbul: İletişim Yayınları.

Düvenci Sabri B. ve Ruken Öztürk, (2014). Postmodernizm ve Sinema. İstanbul: Dipnot Yayınları. Eagleton, Terry, (2010). Estetiğin İdeolojisi. İstanbul: Doruk Yayınları.

Frisby, David (2012). Modernlik Fragmanları. İstanbul: Metis Yayınları.

Jay, Martin, (2012). Deneyim Şarkıları. İstanbul: Metis Yayınları.

Kant, Immanuel (2006). Yargı̊ücünün Eleştirisi. Ankara: İdea Yayınları.

Klossowski, Pierre (1999). Nietzsche ve Kısırdöngü. İstanbul: Kabalc1 Yayınları.

Köse, Hüseyin, (2012). Flanör Düşünce. İstanbul: Ayrıntı Yayınları.

May, Tod, (2012). Yeni Girişimciler: Foucault ve Tüketim Toplumu. Cogito: Michel Foucault, sayı: 70-71,İstanbul: YKY. s.96-106.

McRobbie, Angela. (1999). Postmodernizm ve Popüler Kültür. İstanbul: Sarmal Yayınları.

Nietzsche, Friedrich, (2000). Ecce Home Kişi Nasıl Kendisi Olur. İstanbul: Yapı Kredi Yayınları.

Nietzsche, Friedrich, (2001). Böyle Buyurdu Zerdüşt. Ankara: M.E.B. yayınları.

Özbek, Meral, (2000). Walter Benjamin Okumak II. Ankara Üniversitesi SBF Dergisi 55-3. Ankara: Ankara Üniversitesi, s.104-131.

Roberts, John, (2013). Gündelik Hayatın Felsefesi. İstanbul: Doruk Yayınları.

Simmel, Georg, (2003). Modern Kültürde Çatışma. İstanbul: İletişim Yayınları.

Sütçü, Özcan Yılmaz, (2013). Ortak Bir Dünya Deneyimi: Hikâye Anlatıcısı. Ethos: Felsefe ve Toplum Bilimlerde Diyalog Temmuz 6(2). 76-92.

Ümer, Engin, (2017). Tekinsizin Estetiği ve Sanat Yapıtı. SDÜ ART-E GSF Dergisi. Cilt: 10 Sayı:19. Malatya: Süleyman Demirel Üniversitesi GSF. s.96-126. 
Ümer, Engin, (2016). Adorno, Debord ve Baudrillard'da Kültür ve Sanat. Gazi Sanat ve Tasarım Dergisi, say1: 17. Ankara: Gazi Üniversitesi GSF. s.171-187.

Yacavone, Kathrin, (2015). Benjamin, Barthes ve Fotoğrafin Tekilliği. İstanbul: Hayalperest Yayınları.

Witte, Bern. (2002). Walter Benjamin. İstanbul: Yapı Kredi Yayınları. 